University of Chicago Law School

Chicago Unbound

Journal Articles

Faculty Scholarship

1990

\title{
The Selective Funding Problem: Abortions and Religious Schools
}

Michael W. McConnell

Follow this and additional works at: https://chicagounbound.uchicago.edu/journal_articles

Part of the Law Commons

\section{Recommended Citation}

Michael W. McConnell, "The Selective Funding Problem: Abortions and Religious Schools," 104 Harvard Law Review 989 (1990).

This Article is brought to you for free and open access by the Faculty Scholarship at Chicago Unbound. It has been accepted for inclusion in Journal Articles by an authorized administrator of Chicago Unbound. For more information, please contact unbound@law.uchicago.edu. 


\title{
ARTICLE
}

\section{THE SELECTIVE FUNDING PROBLEM: ABORTIONS AND RELIGIOUS SCHOOLS}

\author{
Michael W. McConnell ${ }^{*}$
}

\begin{abstract}
Selective governmental funding impinging upon controversial but constitutionally protected activities raises difficult doctrinal issues. In this Article, Professor McConnell challenges readers across the political spectrum by comparing and contrasting the constitutional implications of governmental funding policies regarding abortions and religious schools. Perceiving that ideology rather than consistent methodology now governs the constitutionality of selective governmental funding, he applies parallel argumentation to analyze governmental decisions to grant or withhold direct and indirect aid for these protected choices. Recognizing that religion and abortion stir strong emotions in the hearts of many, Professor McConnell concludes by offering a theory of selective governmental funding that could promote dispassionate decisionmaking and more predictable results.
\end{abstract}

$\mathrm{T}$

HE government cannot spend money on everything. It must be selective. But selective funding raises problems, especially when it influences citizens in their exercise of constitutionally protected choices. Then, the politics of spending become inflamed with the rhetoric of constitutional rights. In recent decades, the most protracted and intense of these disputes have involved funding of abortions and of religious schools.

These two issues, abortion funding and religious education funding, seem to pose the same question of constitutional law: when is the government's refusal to fund a constitutionally protected choice an impermissible "burden" on the exercise of the right? In both cases, the Constitution protects the right to decide for oneself - whether to have an abortion or to carry the child to term, and whether to obtain a religious or a secular education for one's children. And in both cases, the government funds one alternative and not the other: the Hyde Amendment to the Medicaid Act prohibits the use of federal funds to perform abortions, ${ }^{1}$ and a series of Supreme Court decisions,

* Professor of Law, University of Chicago Law School. The author wishes to thank Albert Alschuler, Mary Becker, Lloyd Cohen, Judge Frank Easterbrook, Clarke Forsythe, Charles Fried, Stephen Gilles, Abner Greene, Larry Kramer, Douglas Laycock, William Marshall, Thomas McAffee, Mary McConnell, Michael Perry, Judge Richard Posner, Daniel Ritchie, Geoffrey Stone, Cass Sunstein, Diane Wood, and participants in the Legal Theory Workshop at Stanford Law School for helpful comments on an earlier draft as well as the James $H$. Douglas, Jr., Fund and the Kirkland \& Ellis Professorship for financial support during the preparation of this Article.

1 The Hyde Amendment has been reenacted each year since 1976 as a rider to the Department 
of which Lemon v. Kurtzman ${ }^{2}$ is the most prominent, effectively prohibit the use of government funds for religious schools. ${ }^{3}$

More interestingly, the arguments made by proponents of abortion funding and religious education funding are essentially the same. For example, Justice Brennan's dissenting opinion in Harris v. McRae ${ }^{4}$ argues that it is unconstitutional for Congress to refuse to fund abortions when under Medicaid it funds live births. His argument can easily be transposed into an argument that it is unconstitutional for the government to refuse to fund religious schools when it funds secular schools:

A poor woman [with school-age children] confronts two alternatives: she may elect either to [send them to secular schools] or to [send them to religious schools]. In the abstract, of course, this choice is hers alone, and the Court rightly observes that [Lemon] "places no governmental obstacle in the path of a woman who chooses to [send her children to religious school]." But the reality of the situation is that [Lemon] has effectively removed this choice from the indigent woman's hands. By funding all of the expenses associated with [secular education] and none of the expenses incurred in [religious education], the Government literally makes an offer that the indigent woman cannot afford to refuse .... [M]any poverty-stricken women will choose to [send their children to secular schools] simply because the Government provides funds for [this], even though these same women would have chosen [religious schools] if the Government had also paid for that option, or indeed if the Government had stayed out of the picture altogether and had defrayed the costs of neither . . . .5

Justice Brennan, of course, would reject the argument as it applies to school funding. But he has never explained why.

of Health and Human Services appropriation bill. For a recent version, see Departments of Labor, Health and Human Services, and Education, and Related Agencies Appropriations Act of x990, Pub. L. No. IoI-I66, § 204, I03 Stat. I159, II77 (1989), which provides that "[n]one of the funds contained in this Act shall be used to perform abortions except where the life of the mother would be endangered if the fetus were carried to term." Id. In the version before the Court in Harris v. McRae, 448 U.S. 297 ( 1980 ), the Hyde Amendment also permitted the use of federal funds for abortions if the pregnancy had been caused by rape or incest that had been reported promptly to the authorities. See id. at 302 .

2403 U.S. 602 (197x).

3 The religious school funding cases are vastly more complicated than this simple description implies, but those complications do not affect the analysis here. For more detailed descriptions and analyses of the cases, see Garvey, Another Way of Looking at School Aid, 1985 SUP. CT. REv. 6r; McConnell, Political and Religious Disestablishment, 1986 B.Y.U. L. Rev. 405; McConnell \& Posner, An Economic Approach to Issues of Religious Freedom, $56 \mathrm{U}$. CHI. L. REV. I, 25-26 (1989); and McKeever, "Forbidden Fruit": Governmental Aid to Nonpublic Education and the Primary Effect Test Under the Establishment Clause, 34 VrLL. L. REv. Io79 (1989).

${ }^{4} 448$ U.S. 297 (I980).

5 Id. at 333-34 (Brennan, J., dissenting) (citation omitted). 
By the same token, Professor Mark Tushnet has observed:

[Conservatives] make the argument that aid to religion is constitutionally required only in the context of aid to nonpublic schools, where they characterize the denial of aid as the imposition of a penalty on parents who choose to exercise their constitutional right to send their children to nonpublic schools. (As far as I know, conservatives are not embarrassed in making this argument and simultaneously supporting the Court's decision in [Harris], that government is not required to provide public assistance to needy women who want to exercise their constitutional right to have abortions. $)^{6}$

Any embarrassment from the inconsistency of positions should be felt on both sides, because virtually everyone who supports funding of abortions opposes funding of religious schools, and virtually everyone who supports funding of religious schools opposes funding of abortions. It is difficult to resist the conclusion that, for most people, these positions are driven more by relative enthusiasm for or hostility to the underlying rights than by a principled understanding of the relation between these rights and government funding.

The Supreme Court's resolution of the two problems has been almost consistent on the surface. It has held in Harris, among other cases, that the government is not required to fund abortions even when it funds live births. ${ }^{7}$ And it has held in Lemon, among other cases, that the government is not required (indeed, it is forbidden) to fund religious schools even when it funds secular schools. ${ }^{8}$ The superficial similarity in result between Harris and Lemon, however, masks a deep dissatisfaction among the Justices with these results. The liberal bloc believes that Harris was wrong and that Lemon was right, while the conservative bloc believes that Harris was right and Lemon wrong. ${ }^{9}$ With the departure of Justice Powell, there may be no Justice on the Court who now agrees with both lines of cases.

${ }^{6}$ Tushnet, Religion and Theories of Constitutional Interpretation, 33 LOY. L. REv. 221, 228 n.27 (1987).

${ }^{7}$ See Harris, 448 U.S. at 326-27; accord Webster v. Reproductive Health Servs., Io9 S. Ct. 3040, 3050-53 (I989) (plurality opinion); Williams v. Zbaraz, 448 U.S. 358, 369 (1980); Poelker v. Doe, 432 U.S. 519, 52 I (I977); Maher v. Roe, 432 U.S. 464, 470 (I977).

${ }^{8}$ See Lemon, 403 U.S. at 625; accord Aguilar v. Felton, 473 U.S. 402, 409 (1985); Grand Rapids School Dist. v. Ball, 473 U.S. 373, 392-93 (I985). Harris and Lemon are not, of course, exactly parallel. Harris holds that the government is not required to fund abortions when it funds childbirth, whereas Lemon holds that the government is forbidden to fund religious schools even though it funds secular schools. Lemon has two aspects: an explicit "establishment" holding that the Constitution forbids the government from funding reli-gious schools and an implicit "free exercise" holding that this selective funding does not violate the rights of religious adherents who include religious education as part of their exercise of religion.

${ }^{9}$ Justices Brennan, Marshall, Blackmun, and Stevens dissented in relevant part in Harris and Webster but joined the majority in the most recent religious school aid cases, Aguilar and 
In this Article, I present the strongest possible argument for each of the logical positions: abortions must be funded but not religious schools, abortions and religious schools must both be funded, neither abortions nor religious schools need be funded, and religious schools must be funded but not abortions. At each juncture, I maintain parallelism in the arguments pertaining to the two rights. By considering the issues together, I hope to mitigate the tendency, in myself as well as others, to approach the problem of selective funding by reasoning backward from a desired result. The analysis is intended to cast light both on the general question of selective funding and on the substantive constitutional law of abortion and religious education.

In discussing public funding of abortions, I treat the constitutional right to abortion as given, notwithstanding my own opinion that Roe $v$. Wade ${ }^{10}$ was wrongly decided. None of my arguments depend on rejection of the abortion right or on hostility to the exercise of that right. Similarly, though less controversially, I treat the decision whether to incorporate a religious element in the education of one's children as constitutionally protected. The Court formally recognized this right in Pierce v. Society of Sisters. ${ }^{11}$ As a doctrinal matter, I treat this as a free exercise right (following the Supreme Court's characterization in $1973^{12}$ ) rather than as a substantive due process right, which was the doctrinal basis in Pierce prior to "incorporation" of the free exercise clause against the states.

Analysis of selective funding problems must include two elements: first, a careful consideration of the nature of the constitutional right implicated by the funding decision, including the nature of the countervailing interests of the government; and, second, a general theory to identify when rights are threatened by selective funding. The most prominent argument for the constitutional rights of abortion and religious education is what I call the "privacy-separation rationale": that the government is not permitted to interfere with fundamentally pri-

Grand Rapids. Chief Justice Rehnquist and Justices White, O'Connor, Scalia, and Kennedy voted to uphold the abortion funding restrictions in Webster; then-Justice Rehnquist and Justices White and O'Connor dissented in relevant part in Aguilar and Grand Rapids, and Justices Scalia and Kennedy have signaled their agreement. See Bowen v. Kendrick, 487 U.S. 589, 624 ( 1988 ) (Kennedy, J., joined by Scalia, J., concurring). Justice Souter has not taken a position.

${ }^{10} 4$ Iо U.S. II3 (x973).

11268 U.S. 5 To (1925). Pierce also recognized a right to send one's child to a nonreligious private school, namely a military academy. See $i d$. at 535 . That is obviously not a free exercise right, and any discussion of that right is beyond the scope of this Article.

12 See Committee for Pub. Educ. v. Nyquist, 413 U.S. 756, 788 (1973). Even after Employment Division v. Smith, Iro S. Ct. I595 (I990), which severely curtailed protections under the free exercise clause, parents' free exercise right to "direct the religious upbringing of their children" remains of the highest order and overrides even "a neutral, generally applicable regulatory law" to the contrary. Id. at I60I \& n.I (quoting and reaffirming Wisconsin v. Yoder, 406 U.S. 205, 233 (1972)). 
vate choices regarding abortion and religion. The bulk of the Article - Part I - analyzes the funding question from this perspective.

In canvassing the four logical funding positions under this perspective, I proceed progressively. In section A, I address and reject the argument that the existence of the establishment clause, together with the lack of any corresponding provision regarding abortion, supports denying funding to religious schools but not denying funding for abortion. In section B, I draw a distinction between a mere failure to fund and the decision to fund one of two mutually exclusive alternative choices and argue that selective funding poses a constitutional problem only in the latter instance. This distinction forms part of a general theory of selective funding and leads to the temporary conclusion that both Harris and Lemon are wrong. In section C, I reconsider this conclusion in light of the nature of the constitutional rights involved, from the points of view of both the aid recipient and the taxpayer. This analysis suggests that Harris and Lemon are correct, because both are entirely consistent with the underlying theory of the constitutional rights. Finally, in section $D, I$ show that even when a selective refusal to fund is otherwise constitutional (because of the nature of the underlying right), a program of taxation and selective spending may nonetheless be unconstitutional if it penalizes individuals for exercising their constitutional rights. Under this standard, Harris is right and Lemon is wrong, because those who obtain an abortion remain entitled to a package of benefits equal in value to those given to persons who do not obtain an abortion, but those who choose to incorporate a religious element in their children's education forfeit the benefit of funding for secular aspects of education as well.

In Part $I$, I extend the analysis of Part I to religious and abortion counseling and to the use of governmental facilities for religion and abortion. This analysis suggests that even if Harris and Lemon are correct, the extension of those holdings in later cases may not be.

In Part III, I reconsider the previous analysis under two alternative conceptions of the constitutional rights involved. The "anti-coercion" rationale posits that the constitutional rights to abortion and religious schooling limit governmental means but not governmental ends: while the government may not use its coercive powers to override individual choices regarding abortion and religious education, it may use noncoercive means to influence those choices. Under this rationale, both Harris and Lemon seem clearly correct. ${ }^{13}$ The "equal protection" rationale holds that these constitutional rights are best understood as protecting historically subordinated groups (women and members of minority religions) from governmental action that will perpetuate and exacerbate their condition of subordination. Under this conception,

13 That is, Lemon's implicit rejection of the free exercise claim to funding is correct. 
both Harris and Lemon are more difficult to defend (Lemon even more so than Harris), though the correct outcomes remain debatable.

Finally, in Part IV, I argue that a general theory of selective funding is vital to an intermediate jurisprudence of constitutionalism in the context of an activist state, lest the expanded powers of government obliterate the boundaries of constitutionally defined liberties.

\section{Under the Privacy-Separation Rationale}

The constitutional recognition of abortion rights and of the free exercise of religion have this in common: both are responses to fundamental differences of opinion about matters deeply important to the individual. Some persons believe that abortion is murder; some believe it is an essential element of a woman's self-governance and wellbeing; and some take positions in between. Similarly, some persons believe that the source of ultimate value and authority is God made incarnate in Jesus Christ; some worship a different God; some believe in no God at all; and some are indifferent and consider the whole question of religion a waste of time. Few who care about these issues concede to the democratic majority the moral authority to resolve their differences. ${ }^{14}$ The theory underlying both $R o e$ and the free exercise clause is that the best solution to the dissension is to "privatize" the decision - that is, to vest the decision in the individual and to grant the collectivity no say in the matter. In both contexts, this approach respects autonomy in an area important to individual identity and keeps the peace. While there are other plausible conceptions of the constitutional rights recognized in Roe and Pierce, this is the most prominent.

Decisions involving abortion must therefore be predicated on governmental agnosticism about the morality or immorality of abortion - that is, of the moral-scientific status of the fetus or unborn child. ${ }^{15}$ Government cannot act on the presupposition that the fetus or unborn child is a human life deserving protection, and it cannot act on the presupposition that the fetus is subhuman and therefore fair game for

14 In the political climate since Roe, opponents of abortion have tended to support returning the issue to the state governments, but in most cases this is no more than a tactical judgment. If a fetus is a person, majoritarian government has no right to refuse to extend protection to it. See Finnis, Natural Law and the Rights of the Unborn, in ABORTION AND THE CONSTITUTION II5, II9 (D. Horan, E. Grant \& P. Cunningham eds. 1987); Noonan, The Root and Branch of Roe v. Wade, 63 NEB. L. REv. 668, 679 (1984). The principled argument for returning the issue to the states is based, like Roe itself, on "agnosticism" about the moral-legal status of the fetus or unborn child. It holds that our decentralized, state-by-state political process is the best available means for reaching a broadly satisfactory and peaceful compromise on this explosive question.

15 By "agnosticism" I mean the position that the government itself does not and cannot know. I do not mean the position that no one can know. 
extermination. Difficult though it may be to maintain this posture of agnosticism, it is the core of the decision in Roe:

Texas urges that . . . life begins at conception and is present throughout pregnancy, and that, therefore, the State has a compelling interest in protecting that life from and after conception. We need not resolve the difficult question of when life begins. When those trained in the respective disciplines of medicine, philosophy, and theology are unable to arrive at any consensus, the judiciary, at this point in the development of man's knowledge, is not in a position to speculate as to the answer. ${ }^{16}$

Thus, Roe holds that the respect that is due unborn life is a controversial matter, which the Constitution leaves to the conscience of each pregnant woman with respect to the fetus she is carrying.

The privacy logic of Roe thus has two sides. If decisions about abortion must be "private," it follows that the government must neither compel nor forbid, encourage nor discourage, subsidize nor penalize, the practice of abortion. Government must keep its hands off. While the government must not interfere with the rights of those who choose an abortion, it must also recognize that opposition to abortion is based on a conscientious conviction that abortion is the taking of innocent life, a conviction not bigoted but deserving of equal respect. ${ }^{17}$

This posture is for all practical purposes identical to the posture toward religion prescribed by the free exercise and establishment clauses of the first amendment. The government may not legislate on the presupposition that religion in general, or any religion in particular, is correct or salutary, nor on the belief that religion is false or pernicious. Religious truths are controversial propositions, which the Constitution leaves to the conscience of each person. The government's sole involvement with religion is to accord equal respect for the religious (and anti-religious) convictions its citizens hold. This posture is sometimes called "separation" because the religious sphere is distinguished and separated from the sphere of governmental authority. ${ }^{18}$ It might as easily be called "privacy" in the same sense that

16 Roe v. Wade, 410 U.S. II3, I59 (1973).

17 The significance of this "agnosticism" is best seen by contrasting the position of government toward abortion as defined in $R o e$ with the position of government toward racial discrimination. Just as the government must not interfere with abortion rights, it must not discriminate on the basis of race. But the government has no obligation to remain "agnostic" about racial discrimination or to accord respect to racism. The government may - subject to the limits of other constitutional provisions - use its full powers to eradicate racism in our society.

${ }^{18} \mathrm{As}$ an attempt to encapsulate the entire principle of church-state relations, the term "separation" can often be misleading. See McConnell, Accommodation of Religion, I985 SuP. CT. REv. I, 13-14; McConnell, Why "Separation" Is Not the Key to Church-State Relations, Christian Century, Jan. 18, 1989, at 43. Here, it is used in its most normative, attractive sense, as suggesting that religion must be autonomous and independent of government - not in its 
the abortion right is a right of "privacy."19 The "separation of church and state" is thus parallel to "privacy" in Roe because both conceptions involve a metaphorical wall between the public and the private spheres and protect decisionmaking autonomy on the "private" side of the wall. The similarity in the popular conceptions of the two rights is further corroborated by the common use of the term "choice" in the rhetoric of advocates for both causes. "Educational choice" is a shorthand expression for non-discriminatory funding of public and private education. "Pro-choice" means support for abortion rights.

\section{A. Harris Is Wrong; Lemon Is Right}

Some will quickly dismiss any analogy between the abortion and religious education funding questions on the basis of the constitutional text. The first amendment comprises both free exercise and nonestablishment, thereby binding the government to a form of neutrality: the government may "neither advance[ nor inhibit]" the practice of religion. ${ }^{20}$ This means that the government may not impose burdens or "penalties" on the exercise of religion (without a compelling governmental justification) or offer inducements or "subsidies."21 If funding of religious schools is a "subsidy" of religion, it is therefore barred by the establishment clause. Indeed, the only explanation ever provided by the Supreme Court for the constitutionality of denying funding to otherwise eligible educational institutions solely because these schools also express religious opinions (one sentence in one opinion) was that the establishment clause overrides any free exercise right to

more rigid and formalistic sense, in which it can resemble an ideological preference for secularism over religion in the public sphere.

19 Indeed, the Court has used the same language of "privacy" in both contexts. Compare Lemon, 403 U.S. at 625 ("The Constitution decrees that religion must be a private matter for the individual, the family, and the institutions of private choice . . ." (emphasis added)) with Roe, 410 U.S. at 154 ("[T]he right of personal privacy includes the abortion decision . . . ." (emphasis added)).

${ }^{20}$ Lemon, 403 U.S. at $6 \mathrm{r} 2$.

21 On the idea of a "burden" under the free exercise clause, see Lupu, Where Rights Begin: The Problem of Burdens on the Free Exercise of Religion, IO2 HARV. L. REv. 933 (1989); and McConnell \& Posner, supra note 3 , at 38-45. The concepts of penalty and subsidy are notoriously slippery. See Sullivan, Unconstitutional Conditions, IO2 HARV. L. REV. 1413, I433-42 (1989); Sunstein, Why the Unconstitutional Conditions Doctrine Is an Anachronism (with Particular Reference to Religion, Speech, and Abortion), 7o B.U.L. Rev. 593, 601-04 (1990). However, they can be given reasonably workable and consistent definitions. See Baker, The Prices of Rights: Toward a Positive Theory of Unconstitutional Conditions, 75 CoRNELL L. REV. I I85, I246-57 (I990); McConnell, Unconstitutional Conditions: Unrecognized Implications for the Establishment Clause, 26 SAN DiEgo L. REV. 255, 26I-63 (r989). There is no need to define these terms precisely here in order to demonstrate that Harris and Lemon use irreconcilable definitions. 
equal treatment for religious speech. ${ }^{22}$ By contrast, there is no constitutional provision forbidding government subsidy ("advancement") of abortions. Roe prohibits governmental burdens or penalties on the decision to abort, but says nothing about subsidies. This fact alone, some may say, is sufficient to explain why Lemon is right even if Harris is not.

Yet while this position is virtually the conventional wisdom among liberal academics, it is the least intellectually persuasive of the four positions. It has two separate and independent analytical flaws: (I) it rests on an interpretation of Roe that is pro-abortion rather than prochoice; and (2) it assumes that the same policy constitutes unconstitutional "aid" in one context and neutral treatment in the other.

I. The "Establishment" Dimension of Roe. - The argument that Harris is wrong and Lemon is right depends on the assumption that the privacy-separation rationale of Roe lacks an "establishment" component. But the most straightforward reading of Roe is that the right of "privacy" forbids the use of tax monies to subsidize abortions no less than, and for the same reason that, the freedom of religion forbids the use of tax monies for the teaching of religion.

The abortion rights position is said to be "pro-choice" and not "pro-abortion." This must mean that the government is not entitled to favor or promote abortion, any more than it may punish or discriminate against it. Everyone would agree that the theory of Roe would prevent the government from "establishing" abortion by requiring it. If the decision to abort or give birth is "private" - if it is entrusted to the pregnant woman - then the government is no less disabled from forcing than from preventing an abortion. ${ }^{23}$ Critics of

22 See Committee for Pub. Educ. v. Nyquist, 413 U.S. 756, 788 (1973) (recognizing tension between the religion clauses but maintaining that the establishment clause prevents the government from aiding religious schools). Why the establishment clause takes precedence in this context is unexplained; most cases go the other way. See, e.g., McDaniel v. Paty, 435 U.S. $618,627-29$ (1978) (recognizing that the free exercise right of a minister to participate in politics overrides any establishment clause concern to avoid religious power in government); Sherbert v. Verner, 374 U.S. 398,409 ( 1963$)$ (holding that the free exercise clause requires a state to provide unemployment benefits for those out of work for religious but not secular reasons); see also Texas Monthly, Inc. v. Bullock, 489 U.S. I, I8 n.8 ( 1989 ) (plurality opinion) (noting that the Court has permitted benefits that would otherwise be forbidden under the establishment clause because they "were designed to alleviate government intrusions that might significantly deter adherents of a particular faith from conduct protected by the Free Exercise Clause"). Professor Laurence Tribe has concluded that "the free exercise principle should be dominant when it conflicts with the anti-establishment principle." L. TribE, AMERICAN Constitutional LAW \& 14-8, at I20I (2d ed. I988).

${ }^{23}$ To be sure, the Court in Roe did not address this question. Indeed, the opinion approvingly cited Buck v. Bell, 274 U.S. 200 (I927), the infamous decision approving involuntary sterilization. See Roe v. Wade, 4IO U.S. Ir3, I54 (I973). If Buck is good law, maybe forced abortions would be constitutional as well. But if one treats the citation of Buck as thoughtless, it seems far more consistent with the theory of Roe to hold that the government can neither prevent nor require abortion. 
Harris are quick to conclude that what the government may not prevent it also may not discourage. ${ }^{24}$ Presumably that proposition is symmetrical. If the government may not require abortion, why is it not also prohibited from encouraging abortion? If abortion is a "private" decision resting on controversial moral judgments beyond the legitimate reach of government, the Constitution must forbid government-funded grantees from counseling, encouraging, or promoting abortion, ${ }^{25}$ just as it forbids government-funded teachers from promoting religion. ${ }^{26}$

It is but a short step to add that the government may not force anyone to perform or assist in abortions. Why, then, may the government coerce objectors (or, indeed, agnostics on the issue) into supporting abortions through their tax dollars? And if the government cannot offer to pay people to attend church, why can it offer to pay them to perform abortions? A "pro-choice" conception of abortion rights has an "establishment" as well as a "free exercise" dimension, just like the freedom of religion.

It does not necessarily follow from the "establishment" dimension of Roe, however, that the nondiscriminatory funding of both childbirth and abortion is an unconstitutional favoring of abortion - any more than the nondiscriminatory funding of religious and secular education is necessarily an unconstitutional favoring religion. My point is just that there is no reason to distinguish Harris from Lemon on this ground. If Lemon is right, and funding for religious schools is an unwarranted advancement of religion, then abortion funding is likewise unconstitutional and the Hyde Amendment is constitutionally compelled.

2. Inconsistent Definitions of "Subsidy." - Even assuming, however, that "the government obviously has the constitutional authority . . . to make abortion available at no charge to the woman,"27 the mere existence of the establishment clause still provides no coherent basis for contending that Harris is wrong but that Lemon is right. Under this assumption, the Constitution would still demand that the following principles govern religion and abortion rights:

Religion: Government may neither penalize nor subsidize the exercise of religion.

Abortion: Government may not penalize the exercise of abortion rights, but the decision whether to subsidize is within the legislative

${ }^{24}$ See, e.g., Perry, Why the Supreme Court Was Plainly Wrong in the Hyde Amendment Case: A Brief Comment on Harris v. McRae, 32 STAN. L. REv. III3, III7-18 (I980).

${ }^{25}$ See Project Grants for Family Planning Services, 42 C.F.R. \$\$ 59.I-59.I7 (I990).

${ }^{26}$ See infra pp. I023-25.

27 Tribe, The Abortion Funding Conundrum: Inalienable Rights, Affirmative Duties, and the Dilemma of Dependence, 99 HARv. L. REv. 330, 336 (1985) (emphasis in original). 
discretion (so long as the refusal to subsidize is not in substance a penalty).

Although the principles are different, the definitions of the terms (penalty, subsidy) must not be.

To contend that Harris is wrong must mean that the denial of funding is a penalty on the exercise of the abortion right if the government funds childbirth. Using "penalty" consistently, this means that the denial of funding to religious schools must also be a penalty on the exercise of religion if the government funds secular schools. Therefore, if Harris is wrong, governmental funding of religious schools would not "subsidize" those schools; rather, such funding would be required to avoid penalizing those who exercise their rights. As Professor William Marshall has commented, "[i]f the government's refusal to grant a benefit to religious organizations that it provides to nonreligious groups is construed as a penalty, it would suggest that the granting of that benefit to religious organizations could not be considered aid."28 Thus, if Harris is wrong, Lemon must also be wrong.

To contend that Lemon is right must mean that funding religious schools is a subsidy to religion, even if equal funding is given to secular schools. Using "subsidy" consistently, this means that funding abortions must be a subsidy to abortion, even if the government also funds childbirth. Thus, if Lemon is right, Harris must also be right, because under the principles outlined above, there is no constitutional requirement that the government subsidize abortions. The government's refusal to fund religious schools does not burden the exercise of religion - nothing prevents parents from purchasing a religious education for their children (other than a shortage of resources, for which the government is not responsible). By the same token, the government's refusal to fund abortions imposes no obstacle to purchasing an abortion with one's own resources.

To put it another way, if Harris is wrong, the denial of funding is equivalent to a penalty on the exercise of the right, which means that there is a constitutional right to funding of parochial education; and if Lemon is right, funding is a subsidy, which is forbidden in the religious context but relegated to legislative discretion in the abortion context. Using consistent definitions of the terms "penalty" and "subsidy," there is no noncontradictory analysis that yields the conclusion that Harris is wrong and Lemon is right.

Perhaps the mistake in the preceding analysis is the exclusive focus on the effects of the funding decision on the individuals who exercise the right. It is true that without considering subsidizing or penalizing

28 Marshall, Towards a Nonunifying Theory of Unconstitutional Conditions: The Example of the Religion Clauses, 26 SAN DIEgo L. REv. 243, 245 (I989). 
effects, the Court has invalidated some forms of assistance to religious schools simply because it feared "excessive entanglement" between church and state. ${ }^{29}$ But the "entanglement" notion is not independent of the "subsidy" notion: the only forms of entanglement that the Court has found to warrant a finding of unconstitutionality occur when "the very supervision of the aid to assure that it does not further religion renders the statute invalid." 30 In cases in which the Court concludes that aid to religious institutions is not and cannot be a subsidy to religion, any remaining entanglement is insufficient to invalidate the program. ${ }^{31}$ If the subsidy holdings of the parochial school cases are reversed, the entanglement holdings would follow automatically. Without censorship of religious teaching, the entanglement entailed by governmental funding of religious schools would be no greater than the entanglement already entailed by accreditation. Whatever may be the proper role of "entanglement" in establishment clause analysis, it does not provide an independent justification for denying equal treatment to schools on the basis of religious teaching and thus cannot explain the difference between Harris and Lemon.

\section{B. Harris and Lemon Are Both Wrong}

I. The Harris Opinion. - It is no wonder that critics have found the Court's opinion in Harris so unpersuasive. The opinion contains two key arguments, neither of which is satisfactory under the privacyseparation rationale of Roe. First, the opinion claims that the constitutional freedom recognized in Roe does not prevent the state "from making 'a value judgment favoring childbirth over abortion, and . . . implement[ing] that judgment by the allocation of public funds."'32 That statement contradicts the central understanding of the abortion right under the privacy-separation rationale. Under that rationale, the issue of abortion is none of the government's business; the abortion decision is committed to the conscience of each pregnant woman with regard to the fetus she is carrying. To say that the government may make a "value judgment" about the decision violates the privacyseparation premise, just as it would contradict the premise of the free exercise clause to say that the government may make a "value judgment" supporting Christianity over Judaism and "implement that judgment by the allocation of public funds."

${ }^{29}$ See, e.g., Aguilar v. Felton, 473 U.S. 402, 413-I4 (I985).

${ }^{30}$ Bowen v. Kendrick, 487 U.S. 589, 6r5 (1988).

31 See Witters v. Washington Dep't of Servs. for the Blind, 474 U.S. $48 \mathrm{I}, 489$ \& n.5 (1986) (finding it unnecessary to address "entanglement" from nondiscriminatory funding of vocational education for blind persons in religious or nonreligious colleges in absence of a trial record); Mueller v. Allen, 463 U.S. 388, 403 (1983) (finding no excessive entanglement from administration of tuition tax credits).

${ }^{32}$ Harris, 448 U.S. at 314 (quoting Maher v. Roe, 432 U.S. 464,474 (I977)). 
The second and principal argument in Harris, repeated in different words for several pages, is that the abortion right recognized in Roe "does not confer an entitlement to such funds as may be necessary to realize all the advantages of that freedom." 33 "A refusal to fund protected activity, without more," the Court said, "cannot be equated with the imposition of a 'penalty." 34 These statements, while true, are beside the point, for the claimants in Harris asserted no such "entitlement." Their claim was that the government could not fund childbirth while refusing to fund abortion. Their objection was not to a lack of funding, but to selective funding - funding of only one of the two mutually exclusive alternatives, when the choice between them is constitutionally vested in the individual. The Harris opinion failed to address that argument.

2. The Funding of Substitutes. - When, if ever, is the government required to provide the material resources necessary for the exercise of a constitutional right? The Harris Court is surely correct that there is no such general obligation. For the most part, constitutional rights are limitations on the power of government to disturb private rights, not entitlements to governmental assistance. ${ }^{35}$ The government may not interfere with my right to operate a newspaper, but it is not obligated to buy one for me. The government may not interfere with my right to travel, but it need not pay for my ticket. The only cases in which the Court has recognized an affirmative right to governmental assistance have been in the context of criminal prosecutions, in which the Court held that access to lawyers, trial transcripts, or other resources needed for a successful defense was part of the due process required before the government can take away the liberty of the accused, ${ }^{36}$ or when the government is responsible for the individual's inability to take care of himself. ${ }^{37}$

It is insufficient to show that, on the margin, some persons will not exercise a constitutional right in the absence of funding that they would exercise if funding were provided. ${ }^{38}$ If that were sufficient to

${ }^{33}$ Id. at 318 .

${ }^{34}$ Id. at 317 n.I9.

35 See DeShaney v. Winnebago County Dep't of Social Servs., 489 U.S. I89, I98-200 (1989).

36 See, e.g., Douglas v. California, 372 U.S. 353 (Ig63); Gideon v. Wainwright, 372 U.S. 335 (1963); Griffin v. Illinois, 35I U.S. I2 (1956). Although Griffin and Douglas invoked the equal protection clause, the more apt doctrinal basis is due process. See Lassiter v. Department of Social Servs., 452 U.S. I8, 24-33 (I98I); Ross v. Moffitt, 417 U.S. 600, 609-I I (I974).

37 See, e.g., DeShaney, 48, U.S. at I98-200; Estelle v. Gamble, 429 U.S. 97, 103 (1976) (holding that the government must provide medical care to incarcerated prisoners); Katcoff $\mathrm{v}$. Marsh, 755 F.2d 223, 232 (2d Cir. 1985) (holding that the government must provide chaplains to military personnel).

38 Professor Kathleen Sullivan's test for conditions that require strict constitutional scrutiny thus seems overbroad. She contends that the courts should strictly scrutinize "any government benefit condition whose primary purpose or effect is to pressure recipients to alter a choice about 
establish a constitutional violation, every failure to fund would be unconstitutional, a result that is highly implausible and out of keeping with our liberal Constitution. Thus, the obvious facts that fewer women will have abortions under the Hyde Amendment than if the government paid for them, and that fewer children will attend religious schools under Lemon than under a regime of equal funding, do not alone establish constitutional violations.

Nor, from the perspective of the rights of abortion and free exercise, does it matter that the affected persons may be indigent. Failure to fund inevitably will cause a change in decisions on the margin, no matter how wealthy the affected individuals may be. The indigent are more vulnerable to financial pressure, but this is only a matter of degree. If the Hyde Amendment or the refusal to fund parochial schools violates the abortion right or the free exercise clause as applied to the indigent, they are no less unconstitutional as applied to everyone else. ${ }^{39}$ Moreover, if the indigent have a special claim on governmental resources as a matter of constitutional law, ${ }^{40}$ that claim must extend as a logical matter to many more items than abortions and religious schools and must be based on an expansive reading of the equal protection clause rather than on the abortion right or the free exercise clause.

But one can concede that there is no general constitutional obligation on the part of government to provide the resources necessary to exercise a constitutional right (even to the indigent), without conceding the further proposition that the government can direct tax monies to those who exercise their rights in one way while denying funds to those who exercise their rights in another way. Selective funding, as opposed to a mere failure to fund, creates incentives to forgo a constitutional right that would not otherwise be present.

In a sense, every refusal to fund is a form of selective funding, if the government engages in any spending at all. But it does not pressure the right to an abortion for the government to pay for police protection (even if it does not fund abortions), and it might even

exercise of a preferred constitutional liberty in a direction favored by government." Sullivan, supra note 21, at 1499-1500. Perhaps the terms "primary" or "pressure" in this formulation are intended to delimit the analysis in some unspecified way; but if Professor Sullivan means that strict scrutiny is triggered by pure "effects" on the margin, her test sweeps too widely.

${ }^{39} \mathrm{See} i d$. at 1498 ("From the perspective of liberty, all conditions on benefits may look alike: government pressures the speech of the indigent through conditions on welfare no more or less than it pressures the speech of the rich through conditions on capital gains tax benefits or oil depletion allowances." (emphasis in original)).

40 See Michelman, The Supreme Court, 1968 Term - Foreword: On Protecting the Poor Through the Fourteenth Amendment, 83 HARv. L. REv. 7 (1969); Michelman, Welfare Rights in a Constitutional Democracy, I979 WASH. U.L.Q. 659. But see Bork, The Impossibility of Finding Welfare Rights in the Constitution, 1979 WASH. U.L.Q. 695; Winter, Poverty, Economic Equality, and the Equal Protection Clause, 1972 SUP. CT. REv. 41. 
enhance the right to obtain a religious education for the government to finance public transportation (even if it does not fund religious schools). We can divide all activities that might be funded by the government into three categories: (I) those that are substitutes for the activities to which we have a constitutional right, (2) those that are complements to the protected activities, and (3) those that are unrelated to the protected activities. Only the funding of substitutes raises a constitutional problem.

To illustrate the point, assume there is a constitutional right to eat hamburgers. Assume further that hot dogs are a substitute for hamburgers (a person will eat either a hot dog or a hamburger, but not both), that round buns are a complement to hamburgers (a person is more likely to eat a hamburger if he has a round bun than if he does not), and that radios are unrelated to the demand for hamburgers (a person is neither more nor less likely to eat a hamburger if he has a radio). If the government subsidizes none of the items, there is no pressure on the constitutional right. If the government subsidizes radios but not hamburgers, the effect is almost the same. If the government subsidizes round buns but not hamburgers, the effect will be to increase the consumption of hamburgers. If the government subsidizes hot dogs but not hamburgers, however, the consumption of hamburgers will decline. Only in this last case does the selective funding pose a constitutional problem. ${ }^{41}$

The concept of a substitute, however, must be defined narrowly. Many foods are substitutes for hamburgers. But if the government subsidizes fish (and nothing else), the effect on hamburger consumption will be minimal. Indeed, hamburger consumption will decline no more than consumption of frozen lasagna, lima beans, or any other food. If there are many "substitutes" and only one or a few of them are subsidized, any effect on the protected right is diluted; it approaches the subsidy of an unrelated activity. Only when there is a limited set of alternatives, and almost all of them are funded except for the protected right, will the pressure on the right be sufficient to pose a constitutional problem.

3. Application to Harris and Lemon. - It is sometimes argued that abortions must be funded if all other medically necessary procedures are funded. In other words, it violates the Constitution to "single out" abortion as the only medical procedure not funded under Medicaid. But this challenge is not valid. Other medical procedures funded under Medicaid are not substitutes for abortion. They are, if anything, complementary goods; a woman whose other medical needs

41 This analysis follows the economic understanding of taxes and subsidies. According to standard microeconomic theory, governmental funding of a substitute is equivalent to a tax, and governmental funding of a complement is equivalent to a subsidy. 
are met is more - not less - likely to purchase an abortion than if she had no Medicaid benefits at all. The parallel under Lemon would be to argue that the government must fund religious classes if it funds education in all other useful fields of knowledge. But to teach a child reading, for example, does not substitute for teaching him religion; indeed, reading education indirectly subsidizes religious education because a person must be literate to read the scriptures.

Far more persuasive is the argument that the Hyde Amendment is unconstitutional because under it the government pays for the costs of childbirth but not abortion. Pregnancy is a medical condition that requires care. There are two ways to deal with pregnancy: abortion or childbirth. Under the privacy rationale of Roe, the government has no legitimate interest in which course is taken. Its only interest is to ensure that, whichever course is taken, the health and safety of the mother (and child, if she decides to give birth) are protected. Selective funding creates a clear incentive, at least in terms of shortterm financial considerations, ${ }^{42}$ to bring the child to term.

A similar analysis applies to religious education. While the government can pay for secular subjects without having to pay for religious subjects, it cannot pay for secular schools without paying for religious schools. Secular and religious schools are substitutes, and the first amendment prohibits the government from influencing the decision between secularism and religion. Paying for secular schools without paying for religious schools creates a clear incentive to forgo religious education.

Like abortion and childbirth, religious and secular schools are simply different means for accomplishing the same governmental purpose. The most common explanation for public subsidy of elementary and secondary education is that it contributes to a literate, numerate, civil, informed, and potentially productive citizenry - an end that benefits both the students and the rest of society. ${ }^{43}$ The question is whether these objectives can be attained as well in a religious environment. The best available social science evidence confirms that private religious schools are at least as effective as public secular schools under these objective standards, ${ }^{44}$ and cost much

42 Abortions are generally less expensive than childbirth. See Harris, 448 U.S. at 355 n.9 (Stevens, J., dissenting) (noting that the average cost of an abortion in Illinois in I979 was \$15o, while the average cost for childbirth was $\$ 1350)$. And even if the medical costs of childbirth are paid by the government, the large part of the financial burden of child-rearing lies ahead. Thus, even under the Hyde Amendment, abortion is the cheaper option in strictly financial terms.

43 See McConnell \& Posner, supra note 3 , at $\mathrm{x} 6-\mathrm{x} 7$.

44 See J. Coleman, T. Hoffer \& S. Krlgore, High School Achizvement: Public, Catholic, AND Private Schools CoMpared 122-78 (1982) (summarizing research data). The average sophomore attending private school scored above the average public school sophomore in every tested area. See id. at 124. Moreover, private schools are especially beneficial for 
less. ${ }^{45}$ Just as paying the medical expenses for both abortion and childbirth would equally advance the state interest in the health and safety of pregnant women, funding both religious and secular schools would equally advance the state interest in an educated citizenry.

This argument leads to the provisional conclusion that Harris and Lemon are both wrong. When the right to choose between two mutually exclusive courses of action is constitutionally vested in the individual, the government may not fund one of the courses of action but not the other without a sufficiently important justification for doing so. The government is not required to fund childbirth, but if it funds childbirth it must also fund abortion. The government is not required to fund secular schools, but if it funds secular schools it must also fund religious schools.

4. The Question of Resource Conservation. - It might be thought that the conservation of scarce resources is a sufficient reason for refusing to extend funding to abortions and religious schools. That was the explanation President Bush recently gave for not actively supporting tuition tax credits for private schools. ${ }^{46}$ But this explanation must be rejected, for two reasons. First, it is not at all clear that the government saves money by denying funding. To be sure, if a woman otherwise eligible for Medicaid pays for her own abortion, the government has saved the price of an abortion. Likewise, if a family otherwise eligible for a free elementary and secondary education pays for a child's tuition at a private religious school, the government has saved the cost of an education. But if, instead, the woman succumbs to the pressure of the selective funding scheme and carries her child to term, the government must pay that cost (a cost far higher than the cost of an abortion ${ }^{47}$ ), not to mention the probable increased welfare cost of the baby. And if the financial pressure of unsubsidized private school tuition, on top of the property taxes earmarked for public education, becomes so large that families send their children to public schools, then the government must pay that cost (generally, a cost much higher than private religious school tuition ${ }^{48}$ ).

students of minority races and lower income and educational backgrounds; in private schools, these students tend to score higher than do similar students in the public schools. See id. at 144 .

45 See Sonstelie, The Welfare Cost of Free Public Schools, 90 J. PoL. Econ. 794, 803 (I982) (calculating that the cost of a private education is $37 \%$ of the cost of a public education of equivalent quality).

${ }^{46}$ See Bush Rejects Tax Break for Private School Cost, N.Y. Times, Mar. 30, 1989, at Azo, col. 3 .

47 See supra note 42. But see Hardy, Privacy and Public Funding: Maher v. Roe as the Interaction of Roe v. Wade and Dandridge v. Williams, I8 ARIz. L. REv. 903, 926-27 (1976) (arguing that a systematic provision of abortions is more costly because of repetitive abortions and medical complications).

48 See Sonstelie, supra note 45 , at 803 . 
Depending on the circumstances, Lemon and the Hyde Amendment both might increase the burden on the public fisc.

But even if selective funding measures did save money, their constitutionality would still be doubtful. The same amount of money could be saved (again, assuming money is saved) by reducing payments for both alternatives proportionately. Scarce financial resources cannot justify either Lemon or the Hyde Amendment.

\section{Harris and Lemon Are Both Right}

If the Hyde Amendment is constitutional, it must be because the government has legitimate reasons - reasons not based on hostility to the abortion right - for funding childbirth and not abortions. ${ }^{49}$ If the refusal to fund religious schools is constitutional, it must be because the government has legitimate (again, non-hostile) reasons to consider secular public schools more deserving of public subvention than private religious schools. In this section I argue that the nature of the rights themselves supply those reasons. I divide the argument into two parts: (I) legitimate reasons for refusing to fund abortions and religious schools, which do not apply to childbirth and public schools; and (2) legitimate reasons for funding childbirth and public schools, which do not apply to abortions and religious schools.

I. Non-Hostile Reasons for Refusing to Fund Abortion and Religious Schools. - The proponents of abortion funding believe that the government's reasons for refusing to fund are illegitimate - that is, the government's refusal is hostile to the abortion right. Indeed, critics of the decision in Harris have claimed that it is in irreconcilable conflict with the privacy rationale of Roe. Professor Michael Perry goes so far as to say that Harris is "plainly wrong," that its "wrongness ... is beyond debate," and that it is "radically inconsistent" with the "binding constitutional doctrine" of Roe. ${ }^{50} \mathrm{He}$ therefore joins Justice

49 One preliminary definitional point must be made. To claim that the reasons for selective funding must not arise from "hostility" to the right (whether abortion or religious education) is not to rely on subjective intent, in the sense that the legislators (or judges acting as decisionmakers) were personally hostile to the right. Claims of interference with substantive liberties, in contrast to equal treatment claims, have nothing to do with subjective legislative motivation. The proper question is whether there are reasons for funding childbirth and not abortion, and for funding secular schools and not religious schools, that could be accepted even by proponents of the affected rights. Reasons are "hostile" if they depend for their persuasive power upon antipathy to the exercise of the rights in question. Of course I do not mean that the reasons must be so powerful that proponents of the affected rights would necessarily agree that they outweigh other considerations; I mean only that a reason is not "hostile" if a proponent of the affected right would (or should) agree that the reason "counts" in favor of the decision to fund selectively.

50 Perry, supra note 24 , at III4. 
Marshall's claim that the Court's approval of the denial of funding for abortions is "the most vicious attack[ yet devised" on Roe. ${ }^{51}$

This view fails to appreciate the full significance of the privacyseparation rationale of Roe. Under that rationale, the government is required to leave all aspects of the decision about abortion in private hands. It follows logically that the government is permitted - indeed, it may even be required ${ }^{52}$ - to refuse to fund abortions. Roe was not, after all, an affirmation of the proposition that abortion is morally unobjectionable. It was an affirmation that the question of the morality of abortion is deeply contested and that the government should not resolve the issue. As Professor Catharine MacKinnon has noted, "framed as a privacy right a woman's decision to abort would have no claim on public support and would genuinely not be seen as burdened by that deprivation." 53

The dissenting opinions in Harris unintentionally confirm that the pro-funding position departs from the privacy-separation rationale of Roe. They are studded with language suggesting that the performance of an abortion, at least in some circumstances, is a positive good not merely that the protection of a woman's choice is good, but that the performance of the abortion is good. Justice Marshall, for example, described the Hyde Amendment as having "a devastating impact on the lives and health of poor women." 54 This assessment presupposes that abortions promote life and health - a conclusion that is deeply controversial and that, Roe held, neither the legislatures nor the courts are entitled to make or act upon. Justice Blackmun commented, among other things, that as a result of the decision in Harris, "the 'cancer of poverty will continue to grow'; and 'the lot of the poorest among us,' once again, and still, is not to be bettered." This, too, is a conclusion predicated on the view that abortion is a good - an appropriate means for combating poverty. Finally, Justice Stevens supported his claim that "the harm inflicted upon women in the excluded class is grievous" with a list of "examples of serious physical harm" that were said to have been caused by the nonperformance of abortion. ${ }^{56}$ None of their arguments even purports to

\footnotetext{
${ }^{51}$ Beal v. Doe, 432 U.S. 438,455 (I977) (Marshall, J., dissenting); see also Maher v. Roe, 432 U.S. 464,483 (1977) (Brennan, J., dissenting) ("None can take seriously the Court's assurance that its 'conclusion signals no retreat from Roe' . . ." (quoting Maher, 432 U.S. at 475)).

52 See supra pp. $997-98$.

53 MacKinnon, Roe v. Wade: A Study in Male Ideology, in ABortion: MoRAL AND LEgal Perspectrves $45,52-53$ (J. Garfield \& P. Hennessey eds. I984).

${ }^{54}$ Harris, 448 U.S. at 348 (Marshall, J., dissenting).

$55 \mathrm{Id}$. at 349 (Blackmun, J., dissenting) (quoting Beal, 432 U.S. at 463 (Blackmun, J., dissenting)).

${ }^{56} \mathrm{Id}$. at 353 \& n.5 (Stevens, J., dissenting).
} 
preserve a posture of neutrality toward the divisive moral question of abortion. ${ }^{57}$ All three presuppose an answer to that question.

The dissenters' arguments thus present the mirror image of the majority's claim that the government can make "'a value judgment favoring childbirth over abortion." 58 Both sides reach a value judgment about abortion and treat funding as a vehicle for setting national abortion policy. But that is precisely what Roe states the Constitution does not allow. This is unfortunate for both sides because one need not make a "value judgment" about abortion in order to find legitimate, non-hostile reasons for refusing to fund abortions. True adherence to the privacy-separation rationale supplies the answer.

To illustrate this point, let us return to the logic of Lemon. To say that a decision is "private" is to say that the public has no legitimate stake in the decision, one way or the other. This affects both regulation and spending. The federal government is authorized to tax and spend only to promote the "general Welfare,"59 that is, to advance public purposes. Even in the absence of an establishment clause, the federal government would have no authority to tax and spend for the support of religion - hence the argument, made by James Madison among others, that the religion clauses were unnecessary in light of the Constitution's careful enumeration of the powers of the federal government. ${ }^{60}$ If a matter is so private that the public has no right to take a position on it, it falls outside any plausible definition of the "general Welfare."

When a matter has been constitutionally declared "private" precisely because of intractable public dissension, there is all the more reason to refrain from public subvention. Taxation is coercion, and to require taxpayers to support religions they do not accept is understood to violate their religious conscience. In the words of the Virginia Act for Establishing Religious Freedom, passed in I785, "to compel a man to furnish contributions of money for the propagation of opinions which he disbelieves, is sinful and tyrannical."61

Abortion funding in these respects is no different from the funding of religion. Having been declared private, the abortion decision can-

57 Only Justice Brennan's dissent generally limited itself to the protection of the woman's right to choose. See id. at 329-30 (Brennan, $\mathrm{J}_{-2}$ dissenting).

58 Harris, 448 U.S. at 314 (quoting Maher v. Roe, 432 U.S. 464,474 (1977)).

59 U.S. CoNST. art. I, $\$ 8$, cl. I.

${ }^{60}$ See 3 The Debates in the Several State Conventions, on the adoption of the FEDERAL Constitution 330 (J. Elliot 2 d ed. 1836 ) (speech by Madison at the Virginia Ratifying Convention on June 12, I788); The Federalist No. 84, at $51_{3}$ (A. Hamilton) (C. Rossiter ed. 196r); see also McConnell, The Origins and Historical Understanding of Free Exercise of Religion, I03 HARV. L. REv. 1409, I477-80 (I990) (discussing the Federalist argument against a free exercise amendment).

61 Act for Establishing Religious Freedom ( 1785 ), reprinted in 5 P. KURLAND \& R. LERNER, The Founder's Constitution 84,84 (1987). 
not be transformed into a matter of the "general Welfare" for purposes of taxing and spending. For those who consider abortion to be murder, it is "sinful and tyrannical" to require them to participate in it with their tax dollars. At the very least, respect for the consciences of those who believe abortion is murder should count as a legitimate basis for Congress to decide not to devote coerced tax dollars to that use. ${ }^{62}$ This reason is not "hostile" to the abortion right because a proponent of abortion rights can and should respect the conscientious position of fellow citizens who believe they should not be coerced into supporting something they consider to be murder - just as a proponent of religion can and should respect the right of nonbelievers to be free from coerced support for a church. ${ }^{63}$

This principle is not unique to abortion or religion. It is well established that individuals may not be forced to contribute to political advocacy with which they disagree. ${ }^{64}$ Similarly, Congress frequently bars the use of appropriations for activities that significant groups of taxpayers seriously and conscientiously disapprove of, even though it takes no action to prevent private expenditures on the same activity. ${ }^{65}$ Indeed, this is not unusual even when the defunded activity is protected by the Constitution. Perhaps the most notorious recent example

62 See Epstein, The Supreme Court, 1987 Term - Foreword: Unconstitutional Conditions, State Power, and the Limits of Consent, I02 HARv. L. REv. 4, 92-94 (x988); Hardy, supra note 47, at 933-38; Sunstein, Is There an Unconstitutional Conditions Doctrine?, 26 SAN DIEGo L. REv. 337, 343 ( $\mathrm{rg} 8 \mathrm{9}$ ). Professor Epstein goes so far as to argue that public funding of abortions would violate the free exercise rights of those who conscientiously oppose abortion. See Epstein, supra, at 92. This interpretation goes well beyond any free exercise right recognized by the Court. See, e.g., Tilton v. Richardson, 403 U.S. 672, 689 (197I) (holding that extension of federal construction grants to religious colleges did not violate the free exercise rights of objecting taxpayers).

${ }^{63}$ In arguing against Harris, Professor Tribe labeled the "grave moral or religious qualms that some people might entertain about performing, or even helping to finance, an abortion" as "irrelevant to the question of government funding of abortions through tax receipts." Tribe, supra note 27 , at 339. This, he says, is because the tax dollars used for abortions are not "traceable" to persons who object to this use. Id. at 340. In a footnote, he argues in the alternative that objectors could be permitted to obtain refunds. See id. at 340 n.38. Nowhere does he explain why these methods of taxpayer disassociation, which have been emphatically rejected under the establishment clause, are more adequate in the abortion context. Under Professor Tribe's logic, there could be no conscientious objection to using general tax revenues to build a church, because this could be done "without necessarily using tax revenues traceable to objectors." Id. at 340. This view suggests, at a minimum, that Flast v. Cohen, 392 U.S. 83 ( $\mathrm{g} 988$ ), which held that individual federal taxpayers are sufficiently injured by governmental expenditures in support of religion that they have standing to challenge such expenditures under the establishment clause, see id. at I03, was wrongly decided. On the "traceability" point, see McConnell, supra note 3, at 450-52. On the refund point, see $i d$. at 448-5o.

${ }^{64}$ See, e.g., Keller v. State Bar, I Io S. Ct. 2228, 223I (I990); Abood v. Detroit Bd. of Educ., 43r U.S. 209, 232-37 (1977).

${ }^{65}$ See, e.g., Cammarano v. United States, 358 U.S. 498, 513 (I959) (addressing lobbying expenditures). 
is Bob Jones University $v$. United States. ${ }^{66}$ The question in Bob Jones was whether the Internal Revenue Service could revoke the taxexempt status of a private school that forbade interracial dating and earlier had excluded all black students. Because these practices were found to be based on a sincerely held religious tenet, the Court assumed that it would be unconstitutional to "prevent" the school from enforcing its policies. ${ }^{67}$ The Court nevertheless upheld the withdrawal of the tax exemption on the ground that racial discrimination is "at odds with the common community conscience" 68 and the public is therefore entitled to refuse to be "indirect and vicarious 'donors."

To be sure, the government necessarily makes many expenditures despite the conscientious objections of large numbers of taxpayers expenditures on armaments, for example. For the most part, there is no constitutional remedy for this. ${ }^{70}$ It is surely the case, however, that the objectionable character of an expenditure is a legitimate argument against it in the political arena. ${ }^{71} \mathrm{~A}$ responsible legislator would attempt to confine the taxing and spending power of the government, as nearly as possible, to matters of genuine public concern and to avoid needlessly trammeling the consciences of taxpayers. And the example of arms expenditures highlights the distinction between these expenditures, on the one hand, and religion and abortion on the other: armaments are a quintessential public good, while religion and abortion have been constitutionally declared to be within a zone of privacy.

Therefore, as in the case of government funding of religion, the privacy-separation rationale provides ample justification for the government's refusal to fund abortions. When the decisions are private, they should be left to the institutions of private choice. The public,

${ }^{66}{ }_{46}$ I U.S. 574 ( 1983$)$.

67 Id. at 604; cf. Roberts v. United States Jaycees, 468 U.S. 609, 620 (I984) (noting that some truly private organizations have a constitutional right to refuse to admit members on the basis of sex or other invidious characteristics).

${ }^{68}$ Bob Jones, $46 \mathrm{I}$ U.S. at 592.

${ }^{69} \mathrm{Id}$. at $59 \mathrm{r}$. Bob Jones University's sincere religious doctrine regarding race relations casts doubt on the Court's holding that the moral repugnance of the school's practices could be a proper basis for a tax penalty. See Cover, The Supreme Court, I982 Term - Foreword: Nomos and Narrative, 97 HARv. L. REv. 4, 67 (1983); Laycock, Tax Exemptions for Racially Discriminatory Religious Schools, 60 TEx. L. REv. 259, 263, 269 (1982). When free exercise considerations are not present, however, the government is undoubtedly entitled to withdraw tax exempt status from racially discriminatory institutions.

70 See United States v. Lee, 455 U.S. 252, 260 (1982) (stating that because of the high public interest in maintaining a sound tax system, religious beliefs in conflict with the government's use of tax monies afford no basis for resisting the tax).

71 Professor Tribe has pointed out that many liberal members of Congress were embarrassed in arguing against the Hyde Amendment because they had recently argued that opponents of the Vietnam War had a legitimate objection to being taxed to pay for governmental activity they found deeply immoral. See L. Tribe, Abortion: The Clash of Absolutes 158 (rg9o). 
which includes conscientious opponents of religion and abortion, should not be forced to pay for either.

2. Legitimate Reasons for Funding Childbirth and Public Schools. - The preceding discussion argued that the privacy-separation rationale of Roe and Lemon justifies refusing to fund abortions and religious education. But this is not the full extent of the selectivity of funding. Not only does the government refuse to fund abortions and religious education; it also funds their substitutes, childbirth and public schools. An adequate defense of the results of Harris and Lemon requires legitimate reasons (reasons not stemming from objective hostility to abortion or religion) that support the funding of childbirth and public schools but not the funding of abortions and religious schools. It would not be legitimate to fund childbirth if the only significant effect were to discourage abortions, or public schools if the only significant effect were to discourage religious education.

An analogy might be drawn to the funding of Republican but not Democratic political commercials. All of the arguments of the preceding discussion could be made to explain the refusal to fund Democratic commercials: the public is deeply divided; it would be tyrannical and unfair to coerce Republican taxpayers to support a political cause in which they do not believe; while Democrats should be free to advertise on their own and should be protected from any interference, they are not entitled to public subvention; neutrality consists in neither interfering with nor subsidizing the Democrats' commercials. But these arguments fall flat if the government is funding Republican commercials. Do proponents of abortion and religion have a similar right to complain when childbirth and public schools receive public subsidies?

One obvious difference in the Republican-Democratic selective funding scheme is that Republican commercials are no less controversial than Democratic. In contrast, although there are deep divisions over the morality of abortion, few, if any, believe that childbirth is immoral. Proponents of abortion rights do not have any moral objection to childbirth; they believe that a pregnant woman should be free to choose whichever alternative seems best to her. ${ }^{72}$ Using tax dollars to pay for childbirth does not force unwilling taxpayers to support practices they deem morally repugnant.

Moreover, the medical services involved in childbirth serve a function beyond "terminating pregnancy" and improving the mother's health. They are more than just a substitute for abortion; they are also a means of caring for a child. While the appropriate way to deal

72 To be sure, one could believe that the population explosion is a grave threat and that bringing children into the world is morally problematic. But this view is flatly inconsistent with the privacy rationale of $R o e$. It is an argument for using governmental powers, including taxing and spending, to advance collective goals relating to population and reproduction. 
with pregnancy is a controverted issue, everyone agrees that if a child is to be born, the birth should be completed as safely as possible. Medical services at birth should be understood as part of a network of government-funded social services for the benefit of children, which includes prenatal nutrition and medical care, childbirth itself, nutritional programs for infants, tax deductions for dependents, Aid to Families with Dependent Children, free public education, and many more. All of these subsidies are paid to women who carry their fetuses to term; all are denied to those who obtain an abortion. Not even the most dedicated proponent of abortion funding objects to these programs. ${ }^{73}$

Therefore, the crude version of the argument against the Hyde Amendment - that equal benefits must be given to those who have abortions and to those who give birth - is obviously false. There is a difference between programs designed for the benefit of children who are going to be born (even though the programs may incidentally benefit mothers) and programs that are hostile to abortion. If Democrats receive no funding for their ads, they will oppose funding for Republican ads as well. If abortions receive no funding, proponents of abortion, if forced to choose, should and probably would prefer continued funding of childbirth, along with the other forms of assistance to infants, rather than allowing no funding related to pregnancy at all.

The same argument can be made for the funding of secular but not religious schools, though here the argument becomes more problematic. Most religious believers do not consider the teaching of secular subjects in a secular way morally or religiously objectionable. Religious people may prefer religious education, but they do not consider secular education offensive. A significant minority, however, disagrees with this assessment, for reasons that should be taken seriously. Secular education, they think, is not actually neutral toward religion. It undermines religion, both by teaching ethical precepts contrary to religious faith and by creating the impression that religious truth is separate, unrelated, and probably inferior to other forms of truth. This is unacceptable to those who believe that religious truth pervades all of life. ${ }^{74}$ Such people consider secular education antireligious and object to public education funding just as Democrats object to public funding of Republican commercials. ${ }^{75}$ This points to

${ }^{73}$ For example, in the course of arguing against the Harris decision, Professor Tribe advocates "providing improved prenatal care, better financial support for women with infants, and expanded adoption opportunities." Tribe, supra note 27 , at $34 \mathrm{r}$.

74 See Dent, Religious Children, Secular Schools, 6I S. CaL. L. Rev. 863, 865-73 (1988); Gelfand, Of Monkeys and Men - An Atheist's Heretical View of the Constitutionality of Teaching the Disproof of a Religion in the Public Schools, I6 J.L. \& EDUc. 271, 307-14 (1987); Note, The Myth of Religious Neutrality by Separation in Education, 7I VA. L. REv. 127 (I985).

75 See, e.g., Smith v. Board of School Comm'rs, 655 F. Supp. 939, 982, 987 (S.D. Ala.) 
a possible, albeit highly controversial, basis for distinguishing Harris and Lemon.

Putting aside this difficult problem, public schools can be seen as more than merely substitutes for religious schools, just as safe and healthy childbirth is more than just an alternative to abortion. While both public and parochial schools provide basic education, public schools arguably provide an additional public good: public schools are open to all and therefore may be more economically, culturally, racially, and ideologically diverse. Supporters of the public school system often claim that this diversity of population helps both to prepare students for a diverse and pluralistic life after graduation and to inculcate the democratic virtues of toleration and understanding. They might contend, as well, that public schools are better vehicles for communicating the values and priorities of the community to succeeding generations. While private schools may be equally adept at teaching language, math, science, and other curricular subjects, only the public schools will be able to serve the additional public purpose of instilling public mores and aspirations. ${ }^{76}$

The empirical bases for preferring public to private schools, however, largely rest on inaccurate stereotypes. The actual performance of public schools in many parts of the country invites skepticism about their continuing ability to inculcate civic tolerance and teach useful knowledge. ${ }^{77}$ In addition, contrary to popular belief, social science researchers have found private schools to be no'more racially and socially stratified than public schools. ${ }^{78}$ Researcher James Coleman

(ruling that the use of public school textbooks advancing the religion of "secular humanism" violates the establishment clause), $r e v^{\prime} d, 827$ F.2d 684 (IIth Cir. 1987). Several recent studies have concluded that the typical public school curriculum is in fact biased against religion. See P. Vitz, Religion and Traditional Values in PUblic School TeXtbooks: AN Empirical Study 80-81 (r985); C. Haynes, Teaching About Religious Freedom in America (I986); cf. Educators Urge Turn to Studies About Religion, N.Y. Times, July 2, 1987, at Ar6, col. 6 (discussing a report by the Association for Supervision and Curriculum Development calling for an end to the neglect of religion in public school textbooks).

${ }^{76}$ See Fullinwider, The State's Interest in Racially Nondiscriminatory Education, in Public ValUES, PRIVATE Schools 21, 27-30 (N. Devins ed. 1989) (arguing that diversity in the public school system instills the democratic value of mutual respect and that this diversity should be required even of private schools); Levin, Educational Vouchers and Social Policy, in CARE AND EdUCATION OF YOUNG CHILdREN IN AMERICA I03, I16-20 (R. Haskins \& J. Gallagher eds. I980); Sunstein, supra note $2 \mathrm{r}$, at 609-10.

77 See Rebell, Values Inculcation and the Schools: The Need for a Neze Pierce Compromise, in Public Values, Private Schools, supra note 76, at 37, 4I (arguing that the public schools increasingly fail to perform their "traditional socialization function" and may no longer be able to inculcate community values effectively); $c f$. Arons, Educational Choice as a Civil Rights Strategy, in Public Values, PRIvate Schools, supra note 76 , at 63,72 (contending that public schools disempower minorities and suppress their viewpoints because public school systems are majoritarian institutions).

78 African-Americans make up only five percent of the private school population at grade I 2 (as compared to $12.2 \%$ in public schools), but the level of integration within individual private 
has concluded that "Catholic schools come closer to the American ideal of the 'common school,' educating all alike, than do the public schools."79 Moreover, the argument for assimilation and intra-school diversity can slip all too easily into intolerance toward religious minorities who prefer to maintain an identity distinct from the majoritarian culture. ${ }^{80}$ A disguised bigotry may lurk in the assumption that sectarianism breeds intolerance; a secular upbringing can breed its own form of intolerance.

Notwithstanding the lack of evidence supporting the supposed superiority of public schools and the illegitimacy of a policy of enforced religious assimilation, preferential funding for public education is constitutionally defensible, even if not overwhelmingly so. The claims in favor of public schools are plausible even if mistaken, and absent more direct evidence that the decisionmaking process is corrupted by hostility toward religion (or toward those religions most likely to maintain private school systems), ${ }^{81}$ such judgments are within the legislative discretion. Just as funding only childbirth can be defended without disparaging the abortion right, funding only public schools can be defended without denigrating the value of religion or religious education. Therefore, both Harris and Lemon seem correctly decided.

\section{Harris Is Right; Lemon Is Wrong}

In section B, I argued that a selective funding scheme raises constitutional problems if it provides assistance only to one of two mutually exclusive activities, when the choice between the alternatives is constitutionally vested in the individual. According to this argument, both Harris and Lemon were wrongly decided. In section C, however, I argued that the privacy-separation rationale of $R o e$ and Pierce provides a constitutionally sufficient justification for funding

schools is significantly higher, so that the two tendencies approximately cancel each other out. See J. Coleman, T. Hoffer \& S. KILGore, supra note 44, at 29-37. Similarly, though the median income of private school students' families $(\$ 23,200)$ is higher than that of public school families $(\$ 18,700)$, see $i d$. at 38 , "the degree of economic segregation is lower in the private sector as a whole, and in the Catholic and other private sectors separately, than in the public sector." Id. at 4 I. Perhaps most significantly, the educational achievement levels of black and white students are far closer in Catholic than in public schools. See id. at $143-46$.

${ }^{79} \mathrm{Id}$. at $\mathrm{I} 44$.

${ }^{80}$ When the state of Oregon sought to defend its law outlawing parochial schooling struck down in Pierce, it made the following argument to the Supreme Court:

The voters in Oregon might also have based their action in adopting this law upon the alarm which they felt at the rising tide of religious suspicions in this country, and upon their belief that the basic cause of such religious feelings was the separation of children along religious lines during the most susceptible years of their lives, with the inevitable awakening of a consciousness of separation, and a distrust and suspicion of those from whom they were so carefully guarded.

Pierce v. Society of Sisters, 268 U.S. 510, 525 (r925) (argument for Governor Pierce).

${ }^{81}$ See infra p. 1044. 
childbirth but not abortion, and secular public schools but not private religious schools. The argument in section $\mathrm{C}$, if accepted, counters the argument in section B. But the argument in section $\mathrm{C}$ provides no justification for an actual penalty on the practice of a constitutional right. In other words, section $\mathrm{C}$ provides a justification for funding substitutes, but not for imposing a penalty for obtaining an abortion or a religious education. In this section, I argue that Lemon imposes a penalty on the exercise of a constitutional right, but that Harris does not - and thus that the privacy-separation rationale provides a justification for the Hyde Amendment but not for Lemon.

r. The Basic Analysis. - A common understanding of constitutional law is that although the government has no obligation (absent exceptional circumstances) to subsidize the exercise of constitutional rights, it is forbidden to penalize the exercise of those rights. Another way to put the point is that the government may not (without strong, perhaps compelling, justification) structure its funding in such a way that an individual is made worse off than he would have been had he not exercised his constitutional right, except that he may be required to bear the costs of exercising the right itself. For example, a state may impose a toll on interstate travel, but only to recoup the costs imposed on the state by that travel. Although the state is not required to subsidize interstate travel out of its general revenues, it is not permitted to single out interstate travel for special exactions beyond the costs that such travel generates.

It is now widely agreed that in determining whether a person is "better off" or "worse off" it is necessary to consider the effect on government benefits, as well as on common law entitlements. For example, the government may not exclude a discharged worker who is a Seventh Day Adventist from unemployment compensation on the ground that she will not work on a Saturday. ${ }^{82}$ Not working on a Saturday has its costs, but the government may rot add to those costs - either by denying an otherwise available benefit or by imposing a fine or other deprivation. Both are "penalties" on the exercise of the right.

The most extensive body of doctrine bearing on this point has arisen under the free speech clause. The government is not required to subsidize speech. So long as it treats all forms of speech in a content-neutral, nondiscriminatory fashion, it can require speakers to bear the full noncommunicative costs of their expression. Thus, in Cox $v$. New Hampshire, ${ }^{83}$ the Court permitted the state to charge a license fee for engaging in a street demonstration, notwithstanding the fact that holding such a demonstration was protected under the free 
speech clause. The Court insisted, however, that the fee was "not a revenue tax"'; it was set only at a level necessary to meet expenses "incident to" the demonstration. ${ }^{84}$ The logic was that citizens may be required to bear the costs of exercising constitutional rights, but that greater exactions are impermissible because they penalize the exercise of the rights.

Similarly, in Cammarano $v$. United States, ${ }^{85}$ the Court upheld a tax regulation forbidding the deduction of lobbying costs. The effect of this was to require businesses to bear the full cost of exercising their constitutional right to political advocacy, although virtually all other costs of doing business were partially defrayed by the public through tax deductions. In Regan $v$. Taxation with Representation, 86 the Court upheld the withdrawal of tax-exempt status from nonprofit organizations that engage in substantial political lobbying. Because nonprofit organizations are permitted to conduct their lobbying activities through an affiliated organization that is tax exempt but that cannot receive tax-deductible contributions, Taxation with Representation forced these organizations to bear the fill cost of exercising their constitutional right to lobby by requiring them to set up separate organizations, but did not require them to forfeit tax exemptions on their other activities. The effect is that they paid the cost of their lobbying, but otherwise were neither better off nor worse off.

The Court has been equally insistent that absent compelling justification the government may not withhold benefits from those who engage in constitutionally protected speech, beyond the cost of such advocacy to the public. In FCC $v$. League of Women Voters, ${ }^{87}$ the Court struck down a statute forbidding publicly subsidized broadcasters from editorializing. The effect of this statute was not merely to avoid government funding of editorials, but to cut off the subsidies to all of a broadcaster's programming if it editorialized, even with its own funds. As the Court noted, because a "station has no way of limiting the use of its federal funds to all noneditorializing activities, ... it is barred from using even wholly private funds to finance its editorial activity." 88 And in Perry $v$. Sindermann, 89 the Court held that it would be unconstitutional to fire a teacher for his public political positions. The difference between cases such as Cox, Cammarano, and Taxation with Representation and cases such as League of Women Voters and Perry is that the speakers in the first category were merely forced to bear the costs associated with their speech,

84 Id. at 577 (quoting State v. Cox, 91 N.H. I37, I44, r6 A.2d 508, 513 (r940)).

85358 U.S. 498 (r 958 ).

${ }^{86} 46$ I U.S. 540 ( 1983$)$.

87468 U.S. 364 (1984).

88 Id. at 400 .

89408 U.S. 593 (I972). 
while the speakers in the second category lost much more: their entire federal subsidy (in League of Women Voters) and their jobs (in Perry). ${ }^{90}$

2. Application to Harris and Lemon. - Under this analysis, Harris and Lemon are distinguishable. The Hyde Amendment provides that a woman desiring an abortion must pay the cost of the abortion herself, but she continues to be eligible for all other medical services funded under Medicaid. Indeed, the Harris Court commented that "[a] substantial constitutional question would arise if Congress had attempted to withhold all Medicaid benefits from an otherwise eligible candidate simply because that candidate had exercised her constitutionally protected freedom to terminate her pregnancy by abortion." 91 By contrast, under Lemon, if a family chooses to integrate a religious element into primary or secondary schooling, not only must they bear the costs of the religious education, but they also forfeit all public subsidy for education, including secular subjects. It is as if those who get an abortion were thereby excluded from Medicaid. Lemon, then, is structurally parallel to League of Women Voters and Perry. It extracts a penalty - and a large one - for the exercise of constitutional rights. The Hyde Amendment, on the other hand, is more like Cox, Cammarano, and Taxation with Representation. It is a mere refusal to subsidize.

A simple way to distinguish between penalties and mere refusals to subsidize is to compare the financial impact on those who exercise a constitutional right with the impact on similarly situated persons who do not. If the only difference between the two is that the former are "poorer" to the extent of the cost of exercising the constitutional right, the case is one of a mere failure to subsidize. If the difference is greater than the cost of exercising the constitutional right, the case is one of penalty.

If it were possible to accomplish religious objectives through an entirely separate religious component to education (after-school programs, for example, or Sunday School), then Lemon would more closely resemble Taxation with Representation. But many of those who choose religious schools believe that secular knowledge cannot be rigidly separated from the religious without gravely distorting the child's education. ${ }^{92}$ To separate the secular from the religious is to suggest that religion is irrelevant to the things of this world. Many

90 Professor Lynn Baker has applied a similar analysis to public assistance cases under a variety of constitutional provisions. See Baker, supra note 21 , at $1213-46$. The analysis also resembles Professor Ken Simons' distinction between "offers" and "threats." See Simons, Offers, Threats, and Unconstitutional Conditions, 26 SAN DIEGo L. REV. 289, 291-92 (I989).

91 Harris, 448 U.S. at 317 n.I9.

92 See, e.g., A. Greeley \& P. Rossi, The Education of Catholic americans igo-98 (rg66) (observing that religious instruction outside the regular classroom is less likely to inculcate religious values than full-time religious schooling). 
believe that education should reflect the truth that God is the creator of all and is sovereign over all. Moreover, much of the ostensibly neutral curriculum in public schools may undermine religious teaching. ${ }^{93}$ Sex education, Darwinian evolution, and values clarification are ready examples, but the secular orientation of public schools pervades the entire curriculum. From this perspective, it is not sufficient to introduce religious education on the side.

Lemon's holding that any school with a religious component to its program must be denied funding therefore extracts a penalty for exercising a constitutional right. A numerical hypothetical may help to make the point. Suppose that the secular components of parochial school education cost the same as a public school education - say $\$ 4000$ per pupil per year. Suppose further that introduction of a religious element requires an additional expenditure of $\$ 500$ per pupil. Under Lemon, the government cannot fund the $\$ 500$ incremental cost of the religious component. But that is largely uncontroversial. To my knowledge, no one disputes that it is just and proper for the government to refuse to pay the incremental cost of religious components of the education, in light of the conscientious objection many taxpayers have toward mandatory support for religious instruction. What is controversial is that the government refuses to pay for the secular components as well - components toward which no one can have a conscientious objection. In Lemon, for example, the state was forbidden to pay even a portion of the cost of certain strictly nonreligious subjects - "mathematics, modern foreign languages, physical science, and physical education." 94 By exercising their constitutional right to introduce a religious element into their child's education at their own expense, a family forfeits their entitlement to the largest and most important benefit provided by the state for its people. By choosing a religious education, the family loses their right to $\$ 4000$ of secular services.

This argument cannot be made against the Hyde Amendment. A woman who obtains an abortion at her own expense is asked to forfeit nothing. If Medicaid benefits are worth, on average, $\$ 4000$ per year, and if an abortion costs $\$ 500$, the effect of the Hyde Amendment is to require the woman to pay only the $\$ 500$ - the incremental cost of the abortion. She remains eligible for the $\$ 4000$ in non-abortion benefits, the same benefits received by every other Medicaid beneficiary. Thus, although the government has refused to pay for the exercise of the constitutional right to an abortion, it has not penalized the exercise of that right by making other benefits conditional on its waiver.

The conclusion is the same when we compare the benefits available to persons who exercise their rights to abortion and religious education 
with the benefits that would be available if there were no Medicaid or public school programs. A family with children in religious schools would be substantially better off if the government neither provided schools nor imposed property taxes to pay for them. To illustrate this point, let us consider the justification for public school funding offered by some economists: public support is necessary because young children are unable to borrow to pay for early education and repay the loan from their earnings after graduation. ${ }^{95}$ Under this theory, each person is given one free education and each person is required to pay one lifetime's worth of education taxes in return. For the typical person, there is no "subsidy" for education at all: it is like a loan. Each person pays for his own education and no one else's. But for the child who attends a religious school, the financing system is perverse - the child is taxed later in life for a benefit he never received. Had the government stayed out of the picture altogether, families could use money now going for property taxes to pay for tuition to schools of their choice. As it is, religious schoolchildren are required to pay twice.

By contrast, because Medicaid involves redistribution for the benefit of the poor, the Medicaid recipient who obtains an abortion is better off under the Hyde Amendment than she would be without Medicaid at all. Even if Medicaid were a straight social insurance program, she would not be penalized by the Hyde Amendment. Without Medicaid, she would save money in taxes. Depending on whether Medicaid is an efficient program, she might be better or worse off without the program. But her circumstances would not be different from those of any other citizen. Her exercise of a constitutional right has no net effect on the comparison. The Hyde Amendment thus imposes no burden on the right to an abortion, whereas Lemon imposes a substantial burden on the constitutional right to incorporate religious teaching into one's primary or secondary education.

3. The Intermingling of Religious and Secular Education. - It might be argued, however, that the privacy-separation rationale applies whenever religious teaching is so intermingled with secular subjects that even the secular subjects have the effect of promoting religion. This is not a mere hypothetical danger, for one of the key purposes of religious primary and secondary schools is integrating religion into the regular curriculum. ${ }^{96}$ This integration has been

\footnotetext{
95 See McConnell \& Posner, supra note 3, at 17 , 18; West, An Economic Analysis of the Law and Politics of Non-Public School "Aid," z9 J.L. \& ECON. 79, 87-89 (1976).

96 See H. Buetow, The Catholic School 102-I2 (1988). Some of the religious schools in Grand Rapids School District v. Ball, 473 U.S. 373 (1985), for example, took the position that "it is not sufficient that the teachings of Christianity be a separate subject in the curriculum, but the Word of God must be an all-pervading force in the educational program." Id. at 379 (emphasis omitted) (quoting a handbook from one of the schools). This is not to say that in
} 
thought to pose an additional problem under the establishment clause. ${ }^{97}$ When a school is so "pervasively sectarian"98 that its religious and secular components are "inextricably intertwined," the Court has concluded that any aid - even of a secular nature - will inevitably have the effect of promoting religion.

To modify the example in the previous discussion, suppose that secular education costs $\$ 4000$ and that the desired religious components would cost $\$ 500$ if purchased and provided separately. Some items in the school curriculum, however, can accomplish both secular and religious goals. In literature, the class can read The Pilgrim's Progress and the poems of George Herbert instead of Studs Lonigan and Emily Dickinson. In math, some of the problem sets can involve religious examples. An administrator can also conduct chapel, and so on. Note that approaches of this sort can contribute to the religious education without detracting from the educational values of the school at all. Assume that by using these approaches, the religious school can reduce the cost of the religious component from $\$ 500$ to $\$ 300$, at no additional cost to the secular component. As above, the families will pay the incremental cost of the religious education, or $\$ 300$. The question is whether the government can pay the rest. Is religion subsidized when a $\$ 4000$ contribution to a religious school produces $\$ 4000$ in secular value plus $\$ 200$ in religious value?

To determine whether there is a subsidy, we can look at the example from the point of view of either the taxpayers or the affected families. Taxpayers could be injured by the families' decision to incorporate religious elements into their children's secular education if this decision either increased the cost to the taxpayers or decreased the value received by the public from the education. But the families' decision to adopt a religious curriculum does not have either effect: parochial schools, provided they meet the same objective standards of educational quality met by the public schools, produce the same value to the public, and they cost no more. The taxpayers, as taxpayers, should therefore be indifferent. They are getting full "secular value" for their money, to borrow Dean Jesse Choper's expression. ${ }^{100}$ It is impossible to claim that they are being taxed to support a religion they do not share; they are taxed only to support education, without regard to whether religion is also supported.

most religiously affiliated schools, in actual practice, the religious elements are fully integrated into the curriculum.

${ }^{97}$ See McConnell, supra note 3 , at 439-40.

98 Hunt v. McNair, 413 U.S. 734, 743 (r973); accord Roemer v. Board of Pub. Works, 426 U.S. $736,755-59$ (1976).

${ }_{99}^{9}$ Lemon, 403 U.S. at 657 (Brennan, J., concurring); accord Grand Rapids, 473 U.S. at 384; Meek v. Pittenger, 42 I U.S. 349,366 (I975).

100 See Choper, The Establishment Clause and Aid to Parochial Schools - An Update, 75 CALIF. L. REv. 5, I4 (I987). 
From the families' point of view, the question is whether the freedom to use the child's share of public education spending in a religious school creates either an incentive or a disincentive to exercise religion. If the subsidy is no greater than that given to students in secular schools, it obviously creates no such incentive. Those who choose religious education are neither better off nor worse off than those who prefer secular education. Indeed, everyone is better off, in the sense that they have more choices and thus can obtain an education more closely tailored to their preferences.

The Supreme Court has recognized the validity of this argument in the context of so-called "indirect" aid (aid provided to the student or family instead of the school). In Witters $v$. Washington Department of Services for the Blind, ${ }^{101}$ for example, the Court unanimously held that it does not violate the establishment clause for a state to provide assistance for a student's seminary education at a sectarian school under a program to support vocational education for the blind. The "secular value" to the state is that the blind student is equipped for gainful employment, no less than if he had trained to become a computer technician or a physical therapist. Because the state received full secular value, it was constitutionally irrelevant that religious values were concomitantly served. Similarly, the Court has indicated that programs akin to the "G.I. Bill," in which the government pays the cost of tuition without regard to whether the institution is religious or nonreligious, are permissible. ${ }^{102}$ These programs are not "subsidies" to religion because they do not treat those who choose religious education more favorably than others. They are subsidies to education, not to religion. There is no persuasive reason why the same principle should not be extended to primary and secondary schools. ${ }^{103}$

Accordingly, the denial of funding to religious schools cannot be justified by the intermingling of religious and secular components of the curriculum, which is a matter of indifference to the taxpayers and does not affect the incentives of the families involved. Lemon, unlike the Hyde Amendment, thus unjustifiably imposes a significant penalty for the exercise of a constitutional right, beyond merely requiring the

101474 U.S. 48 I (1986).

102 See Committee for Pub. Educ. v. Nyquist, 413 U.S. 756, 783 n.38 (I973); Americans United for Separation of Church \& State v. Blanton, 433 F. Supp. 97, 102-05 (M.D. Tenn.), aff'd mem., 434 U.S. 803 ( $(977)$; Smith v. Board of Governors of the Univ. of N.C., 429 F. Supp. 871, 877-79 (W.D.N.C.), aff'd mem., 434 U.S. 803 (1977).

103 The great practical advantage of "indirect" aid is that the funding mechanism guarantees that individual choice, and not governmental favoritism, will dictate the allocation of funds. The potential for such governmental favoritism might be sufficient justification for excluding religious organizations from discretionary grant programs. But if funds for parochial schools are allocated on a per-pupil basis, there is no more danger of allocative distortion than with an "indirect" funding scheme. 
individual to bear the cost of exercising the right. Rather than being required by the first amendment, the result in Lemon is more likely forbidden by it.

\section{Stricter Separation: Restrictions on Counseling, Commingling Programs, aNd Use of Public Facilities}

Harris and Lemon both involved the problem of direct cash subsidies, which are the simplest, most direct form of public aid. Supreme Court precedent in this context is reasonably uncomplicated: under Lemon and its progeny, direct cash subsidies to parochial schools almost invariably are struck down. ${ }^{104}$ At the other extreme, consensus also exists. Even the staunchest opponents of aid to religion concede that denying churches and religious schools access to such "matters of common right"105 as police or fire protection or access to public highways would be unconstitutional. ${ }^{106}$ And no one believes that the principle of Harris would allow the government to deprive abortion clinics of these forms of public "aid."

The reason these concessions are so uncontroversial is rarely explained; but it is revealing. Services such as police, fire, and roads are monopolies of the government as well as public goods (that is, goods that provide widespread benefits even to persons who do not pay for them). The significance of being government monopolies is that if the government does not provide the services to particular entities (churches or abortion clinics), those entities will not be able to obtain them from alternate sources. Because the services are indispensable, a denial of access ("aid") would therefore be tantamount to destruction. The significance of being public goods is that there is no (or very little) marginal cost to serving an additional consumer. Taxpayers would save nothing (or very little) if churches or abortion clinics were excluded. Exclusion, therefore, would have devastating effects on the private entities excluded while producing almost no benefit to the public. Cash grants are at the opposite extreme: there are multiple sources of cash, and the entire grant is a marginal cost to the taxpayers.

Supreme Court precedent involving forms of aid between these extremes is complicated, contested, and in flux. While this is not the occasion to provide a comprehensive critique, it would be useful to discuss those forms of aid that affect both abortion and religious

104 The sole exception in the Supreme Court is Committee for Public Education and Religious Liberty v. Regan, 444 U.S. 646 (1980), which upheld a statute reimbursing parochial schools for the cost of administering state-prepared standardized tests. See id. at 66o-6r.

105 Everson v. Board of Educ., 33० U.S. I, 6o (I947) (Rutledge, J., dissenting).

106 See id.; see also Roemer v. Board of Pub. Works, 426 U.S. 736, 747 (1976) (rejecting the position that the state cannot provide basic services to religious institutions). 
education. There are three main areas of comparison: (I) restrictions on the speech of government employees and grantees, (2) structural restrictions on government grantees, and (3) restrictions on the use of public facilities. This Part will analyze these attempts to effectuate a stricter "separation" - between government and religion, and between government and abortion - by extending the general theory of Part I.

\section{A. Restrictions on Speech}

In Lemon, the Court held that the "State must be certain . . that subsidized teachers do not inculcate religion." 107 A similar prohibition exists in the public schools, where teachers are strictly forbidden to use their tax-supported position to encourage religion. ${ }^{108}$ The same logic underlies many abortion-related funding statutes. For example, in Webster v. Reproductive Health Services, ${ }^{109}$ portions of the Missouri law not reviewed on the merits forbade "encouraging or counseling a woman to have an abortion not necessary to save her life" with public funds 110 or by public employees within the scope of their employment. ${ }^{111}$ Such restrictions have produced free speech challenges in the context of both abortion and religion. Publicly financed family planning counselors have contended they have the first amendment right to provide abortion counseling, 112 and public school teachers have asserted a constitutional right to express religious convictions to their students. ${ }^{113}$

${ }^{107}$ Lemon, 403 U.S. at 619.

108 See, e.g., Wallace v. Jaffree, 472 U.S. 38, 56-61 (1985); Webster v. New Lenox School Dist. No. 122, 917 F.2d 1004, 1007-08 (7th Cir. I990); Steele v. Van Buren Pub. School Dist., 845 F.2d r492, 1495-96 (8th Cir. 1988); Roberts v. Madigan, 702 F. Supp. 1505, 1518-19 (D. Colo. 1989), aff'd, No. 89-ror4 (roth Cir. Dec. 17, 1990) (1990 U.S. App. LEXIS 21,683); Breen v. Runkel, 6I4 F. Supp. 355, 357-60 (D. Mich. I985).

109 I09 S. Ct. 3040 (I989) (plurality opinion).

110 Mo. REV. STAT. § I88.205 (1986).

111 See id. \$ $188.210 ;$ Webster, $109 \mathrm{~S}$. Ct. at 3053 . The law also forbade any such encouragement or counseling in public facilities, see Mo. REV. STAT. \$ I88.215 (Ig86), a restriction considered below, see infra pp. Io32-33. The Eighth Circuit in Webster struck down all three provisions, but the state appealed only the provision pertaining to counseling with public funds. See rog S. Ct. at 3053. Accepting the state's claim that this provision is directed only to disbursing officers, the Supreme Court concluded that there was no actual case or controversy pertaining to this portion of the statute. See id. at 3053-54.

112 See Massachusetts v. Secretary of Health \& Human Servs., 899 F.2d 53, 72-75 (rst Cir. 1990), petition for cert. filed, 59 U.S.L.W. 3037 (U.S. June 8, 1990) (No. 89-1929); see also Note, The Title X Family Planning Gag Rule, 4I STAN. L. REv. 40I, 408-22 (I989) (arguing that title $\mathrm{X}$ imposes an unconstitutional condition on family planning counselors' free speech).

I13 See, e.g., Smith v. Blue Valley Unified School Dist., 9 Religious Freedom Rptr. (Campbell Univ.) I20 (D. Kan. Apr. 24, I989) (1989 U.S. Dist. LEXIS 4067) (granting summary judgment against an assistant principal who raised a free speech challenge to his dismissal for discussing religious subjects with students); Roberts v. Madigan, 702 F. Supp. 1505, I5I8-I9 (D. Colo. I989), aff'd, No. 89-1014 (Ioth Cir. Dec. 17, I990) (1990 U.S. App. LEXIS 21,683 ) (denying a teacher's asserted right to read the Bible during silent reading periods). See generally J. WHITE- 
The theory behind the restrictions is that the government and its agents must abstain from the debate concerning matters that the Constitution deems private. Assuming the restrictions are evenhandedly set and applied and that they are confined to the teacher, doctor, or counselor's formal activities on behalf of the government, the restrictions seem not only legitimate but unavoidable. When government itself is barred from influencing private choice, it cannot empower agents with special positions to influence students or clients in making that private choice. A teacher, doctor, or counselor who feels compelled to spread (or oppose) the gospel or to advocate (or oppose) abortion should find a position in the private sector. ${ }^{114}$ In the public sector, their speech must be constrained because they are agents and perceived mouthpieces of the government. ${ }^{115}$

This argument presupposes that the teachers and family planning counselors involved are properly treated as agents of the government rather than as independent speakers. While this is probably an unavoidable conclusion in the case of government employees, it is possible that teachers or counselors in publicly funded but privately administered programs should be treated differently. To be sure, in the case of religion, the Supreme Court has not drawn any such distinction. In Bowen v. Kendrick, ${ }^{116}$ for example, the Court analyzed the constitutionality of the Adolescent Family Life Act (AFLA), ${ }^{117}$ which authorizes federal grants to public and private organizations,

head, The Freedom of Religious Expression in the Public High Schools 34-42 (I983) (discussing the first amendment rights of teachers).

114 The First Circuit's contrary argument in Massachusetts overlooks the difference between privately funded and publicly funded activity: "[I] information restrictions are invalid in general [that is, as applied to private physicians], how can they be valid in the limited situations of public funds? It is axiomatic that the government cannot do indirectly (i.e. through funding decisions) what it cannot do directly." Massachusetts, 899 F.2d at 72. Similar logic would suggest that if the government does not have the right to dictate the curriculum of private schools, it does not have the right to dictate the curriculum of public schools. This "reasoning" is an example of the unconstitutional conditions doctrine run riot. If the public-private distinction has any validity (and the privacy-separation rationale rests on just such a distinction), the government's authority to regulate private speech is an entirely different matter from its authority to regulate its own speech through its agents.

115 Some have argued that the nature of the physician-patient relationship sets the title $\mathrm{X}$ restrictions apart, but as a constitutional matter there is no difference between the relationship of a government-funded physician to his patients with respect to abortion counseling and the relationship of a public school teacher to his students with respect to religious communications. Both are professionals. Both have a certain degree of professional autonomy, whether called "medical judgment" or "academic freedom." Both are limited in that autonomy if they work for the government, insofar as the government's authority with respect to "private" matters is limited.

${ }^{116} 487$ U.S. 589 (1988). The author of this Article argued the case in the Supreme Court on behalf of the private intervenors.

$117 \mathrm{See} 42$ U.S.C. $\$ \S 300 z$ to $300 z-10$ (Ig88). 
both secular and religiously affiliated, to provide various services to combat teenage pregnancy, including counseling to promote sexual self-discipline. The plaintiffs alleged that the program constitutes government-funded religious indoctrination. While upholding the program on its face, the Court held that the federal government must ensure that no AFLA grantees "use materials that have an explicitly religious content or are designed to inculcate the views of a particular religious faith."118 This implicitly affirmed that recipients of federal grants are subject to restrictions applicable to the government itself.

The same logic would support imposition of similar restrictions governing title $\mathrm{X}$ grantees with respect to the counseling of abortion. If grantees are governmental actors for purposes of the establishment clause, they are governmental actors for purposes of abortion restrictions. If employees of grantees are private speakers for purposes of speech about abortion, they are private speakers for purposes of speech about religion as well. ${ }^{119}$ To reach a different result in the title $\mathrm{X}$ cases would require the Court to revisit Kendrick.

\section{B. Structural Restrictions on Grantees}

Even if we conclude that the Hyde Amendment itself does not impose a penalty on the exercise of a constitutional right, the analysis in Part I leads to the conclusion that some abortion funding restrictions are unconstitutional. Consider three possible restrictions on the activities of government-funded family planning clinics: (I) the grantee may not use public funds to perform abortions; (2) the grantee may not perform abortions within the same physical facility used for publicly funded family planning services; and (3) organizations that perform abortions anywhere may not receive grants. Restriction (I) was imposed in the pre- $\mathrm{I} 988$ federal title $\mathrm{X}$ regulations. ${ }^{120}$ Restriction (2) was imposed by the 1988 federal title $\mathrm{X}$ regulations. ${ }^{121}$ Restriction (3) has been imposed by some states. ${ }^{122}$

Parallel restrictions arise when religious or religiously affiliated organizations seek grants for the provision of secular public services, such as day care. Under recently enacted federal legislation, poor families will receive financial assistance for obtaining child care while

118 Kendrick, 487 U.S. at $62 \mathrm{I}$.

119 The ACLU Reproductive Freedom Project has conducted the litigation in both Kendrick and the title $\mathrm{X}$ cases, taking inconsistent positions on free speech rights of grantees depending on whether the speech is in favor of abortion or religion.

${ }^{120}$ See 42 C.F.R. $\$ 59.5(a)(5)$ ( 987 ) (providing that grant recipients may not "provide abortions as a method of family planning").

12142 C.F.R. $\$ 59.9$ (r 989 ).

122 See, e.g., 1980 Ariz. Sess. Laws $842,860$. 
the parents work outside the home. ${ }^{123}$ As with abortion, there are three logical possibilities regarding religious participation in publicly funded day care: (I) the grantee may not use federal funds for religious worship or instruction (though remaining free to engage in religious activities out of private funds); (2) the grantee may not engage in religious activities within the same physical facility used for publicly funded day care; and (3) the grantee may not be a religious organization. Even if Harris and Lemon are both right, it should follow that, in both contexts, restriction (I) is constitutional, restriction (3) is unconstitutional, and restriction (2) is a close case, whose outcome depends on the particular facts. ${ }^{124}$

Restriction (I) seems to raise no constitutional question apart from that raised by Harris or Lemon. If the government is not required to fund abortions directly through Medicaid, it is not required to fund abortions indirectly, through aid to abortion providers. Similarly, because the government is not required (indeed, it is forbidden) to

123 See Child Care and Development Block Grant Act of 1990 , enacted in Omnibus Budget Reconciliation Act of $1990, \$ \$ 5081-5082$, Pub. L. No. IOr-508, I990 U.S. Code CoNG. \& ADMIN. NEWS 625 (IO4 Stat. I388). It has been reported that about one-fourth to one-third of day care centers are now church-affiliated. See Congressional Research Serv., Constitutionality of Possible Amendment to S. 5 Removing Certificates From $\S$ Ig(a), at 7 (May 9, I989) (on file at the Harvard Law School Library).

124 Interestingly, even statutory construction is distorted by the strong differences in perception regarding abortion and religion. Section 1008 of title $\mathrm{X}$ of the Public Health Service Act provides that "none of the funds appropriated under this subchapter shall be used in programs where abortion is a method of family planning." 42 U.S.C. $\$ 300 a-6$ (xg88). This language, on its face, incorporates restriction (2): publicly funded family planning services may not be offered in the same program in which abortions are performed. Notwithstanding this language, the First Circuit held that such an interpretation "violates congressional intent because of the effect it would have of limiting family planning programs." Massachusetts v. Secretary of Health \& Human Servs., 899 F.2d 53, 60 (Ist Cir. I990), petition for cert. filed, 59 U.S.L.W. 3037 (U.S. June 8, 1990) (No. 89-1929).

By contrast, $\S 658 \mathrm{M}(\mathrm{a})$ of the Child Care and Development Block Grant Act provides that "[n]o financial assistance provided under this subchapter shall be expended for any sectarian purpose or activity, including sectarian worship and instruction" in child care centers receiving funds directly from government agencies. This appears to incorporate restriction (I): public funds may not be used for religious worship or instruction. (The restriction does not apply to the use of certificates or vouchers given to parents.)

Ironically, the Committee Report accompanying the Act, under the chairmanship of Senator Edward Kennedy, rejected this reading of the restriction as too "narrow" and "technical" and instead found that "an entity receiving any form of financial assistance under this Act shall not include any sectarian activities, worship or instruction in providing child care services under this Act." S. REP. No. I7, Iorst Cong., Ist Sess. 48-49 (r989). Thus, the Committee interpreted the language of the Act as if it incorporated restriction (2) - no day care centers receiving federal funds may engage in religious activities while providing day care services.

Thus, the two statutory provisions have been interpreted in a manner precisely opposite from what their language commands: the narrowly drawn religion restriction is interpreted in a "broad" fashion, while the broader abortion restriction is interpreted in a "narrow" and "technical" fashion. One is forced to conclude that in applying principles of statutory construction, as in interpreting constitutional doctrine, legal consistency has been subordinated to ideology. 
fund religion directly, it can ensure that it is not funding religion indirectly by forbidding grantees from using federal day care money to pay for religious activities. ${ }^{125}$

In contrast, restriction (3) in both contexts goes beyond a mere refusal to fund. An Arizona appropriations bill contained a provision that denied state funding to any nongovernmental "agencies or entities which offer abortions, abortion procedures, counseling for abortion procedures or abortion referrals."126 An entity that performed abortions, even in separate facilities with its own money, thus could receive no family planning funding in that state. The effect of the statute was to impose a $\$ 47,000$ penalty on Planned Parenthood for its privately funded abortion-related activities, a penalty equal to the amount it would otherwise have received from the state. Reasoning that "the State of Arizona may not unreasonably interfere with the right of Planned Parenthood to engage in abortion or abortion-related speech activities, but the State need not support, monetarily or otherwise, those activities,"127 the Ninth Circuit rejected the state's argument that the provision was necessary in order to prevent the "free[ing] up [of other] funds used to support abortion-related activities." 128 However, the court remanded the case to the district court for a determination whether withdrawing all state funds from Planned Parenthood was the only way to ensure that state funds would not be used to support abortion-related activities. ${ }^{129}$ This analysis seems correct. In the context of an organization maintaining separate facilities with distinct accounting records, the state would have no justification for denying aid to one facility simply because another facility performs abortion services; the state could easily track its funds and determine that the grants assist only the "non-abortion" service facility.

With respect to the religion analogue, the suggestion that religious organizations must categorically be barred from participation in all government-funded programs must be rejected. Although favored by the so-called "strict separationists," this has never been the rule in establishment clause cases and has been rejected by the Supreme Court in every case in which it has been seriously advanced. ${ }^{130}$ The privacy-separation rationale requires the government to treat the performance of abortions and the exercise of religion by others as matters

${ }^{125}$ See Bowen v. Kendrick, 487 U.S. 589, 610-14 (1988); Roemer v. Board of Pub. Works, 426 U.S. 736, 759-6r (I976); Hunt v. McNair, 413 U.S. 734, 744-45 (1973); Tilton v. Richardson, 403 U.S. $672,677-80$ (197r).

126 Ig8o Ariz. Sess. Laws 842, 860.

127 Planned Parenthood v. Arizona, 718 F.2d 938, 94I (9th Cir. I983).

128 Id. at 945 .

129 See id. at 946 .

${ }^{130} \mathrm{See}$, e.g., Bowen v. Kendrick, 487 U.S. 589, 608-09 (I988); Hunt v. McNair, 413 U.S. 734, 742-43 (I973); Everson v. Board of Educ., 330 U.S. I, I6-I8 (I947); Bradfield v. Roberts, I75 U.S. 29I, 299-300 (I899). 
of indifference. In both of these contexts, denying federal money for activities that would otherwise be funded would amount to a substantial penalty for exercising one's constitutional rights.

Restriction (2) presents a much closer case. The most prominent example in the abortion context is the I988 title $\mathrm{X}$ regulations, which prohibit grantees from carrying out government-funded family planning services in a facility also used for abortion-related services. ${ }^{131}$ Although prior regulations required only that grantees maintain financial records showing that federal funds were used in accordance with project requirements (which proscribed funding for abortion activity), ${ }^{132}$ the new regulations specify that a title $\mathrm{X}$ project must be "physically and financially separate" from any prohibited abortionrelated services. ${ }^{133}$ The lower federal courts are divided on the constitutionality of these regulations, ${ }^{134}$ and the issue is awaiting resolution by the Supreme Court.

If the establishment clause precedents were followed, there is little doubt that the restrictions would be upheld. In Grand Rapids School District v. Ball, ${ }^{135}$ full-time public school teachers went on an itinerant basis to various schools, public and private, to provide special secular remedial and enrichment courses to supplement the ordinary curriculum. The Court held this "Shared Time" program unconstitutional as it applied to instruction in religious schools. ${ }^{136}$ While the Court did not question that parochial school students were eligible to receive the special instruction, it held that they could do so only in locations physically separate from the religious school. ${ }^{137}$

The Court offered three reasons for this holding. First, it stated that public school teachers temporarily in the "atmosphere" of a religious school "may well subtly (or overtly) conform their instruction to the environment in which they teach, while students will perceive the instruction provided in the context of the dominantly religious message of the institution, thus reinforcing the indoctrinating effect."138 Second, it stated that the symbolic effect of a physical separation is

131 See 42 C.F.R. \& 59.9 (I989).

${ }_{132} \mathrm{See}_{42}$ C.F.R. $\$ \S 59.5,59.208,59.212$ (I987).

${ }^{133} 42$ C.F.R. \$ 59.9 (I990).

134 Compare Massachusetts v. Secretary of Health \& Human Servs., 899 F.2d 53, $72-75$ (Ist Cir. 1990) (holding the regulations unconstitutional), petition for cert. filed, 59 U.S.L.W. 3037 (U.S. June 8, I990) (No. 89-I929) and Planned Parenthood Fed'n v. Bowen, 680 F. Supp. 1465, I477-78 (D. Colo. Ig88) (same) with New York v. Bowen, 690 F. Supp. 126I, 1272-74 (S.D.N.Y. I988) (upholding the constitutionality of the regulations).

135473 U.S. 373 (1985). The author of this Article prepared a brief and presented oral argument in Grand Rapids on the losing side.

136 See id. at 397 .

${ }^{137}$ See id. at $388-89,39$ I, 396 (limiting the rationale of the Court to activities on the premises of religious schools).

138 Id. at 388 . 
important, because allowing the provision of government-funded remedial education on the premises of the parochial school is "a powerful symbol of state endorsement and encouragement of the religious beliefs taught in the same class at some other time during the day."139 Third, the Court feared that governmental financial support of one activity within an integrated facility inevitably subsidizes all the other activities within the facility. ${ }^{140}$ Only by requiring physical separation could the government ensure that its support for one activity (secular education) would not indirectly subsidize the other (religion). ${ }^{141}$ Thus, the effect of Grand Rapids was to impose restriction (2).

The explanation offered by the Department of Health and Human Services (HHS) for the new title $\mathrm{X}$ abortion regulations is substantially identical to the Court's reasoning in Grand Rapids. HHS reasoned first that the new restrictions are needed to prevent governmentfunded counseling that would "encourage, promote or advocate abortion."142 Those who receive government-funded family planning services must be screened from the indoctrinating effect of pro-abortion activity. Indoctrination may be hard to avoid in a facility whose commitment to the "appropriateness of abortion"143 pervades the "atmosphere" and presumably affects the attitudes and conduct of its employees.

Second, HHS reasoned that separate facilities are needed "to prevent existing or potential clients of Title $X$ projects - as well as the general public - from concluding that the government endorses abortion."144 Clients who seek government-funded family planning services might think that the presence of abortion services or counseling within the same facility signals a governmental endorsement of the morality and appropriateness of abortion.

Third, according to HHS, physical separation is needed to prevent indirect subsidies from the government-funded family planning project to the abortion activities of the grantee. "Even where the strictest accounting and charging of expenses is performed," HHS reasoned, "shared facilities inevitably increase the likelihood that a violation will occur, and lead to situations where the assertion that a program does not 'include' abortion amounts to little more than an accounting fiction."145

139 Id. at 392.

140 See id. at 396.

${ }_{141}$ See McConnell, supra note 3 , at 435-40, 456-59.

142 Standard of Compliance for Family Planning Services Projects, 52 Fed. Reg. 33,210, 33,2 II (I987).

143 Id. at 33,212 .

144 Id.

145 Id. Indeed, HHS may have undersold its case. Even in theory, the sharing of joint and common costs will have the effect of making the provision of abortions cheaper than it would be without government funding of the family planning project. 
From entirely different ideological casts of mind, a Supreme Court majority led by Justice Brennan and the Reagan Department of HHS thus concluded that a thorough separation between governmentfunded programs and the activities of religion (in one case) and abortion (in the other) is required, and for the same reasons: indoctrination, endorsement, and indirect subsidies. While the results may well be extreme, one must concede that if the goal is "absolute[" 146 prohibition of government-sponsored or government-financed religious training or abortion, the physical separation embodied in restriction (2) is a logical requirement. At least, the logic is equally powerful, or equally unpersuasive, in the two contexts.

The problem with the pursuit of "absolute" separation is the effect on constitutional interests on the other side of the balance, a problem that received no attention from the Court in Grand Rapids and little attention from HHS. Grand Rapids forced the parents of children needing special services to choose between receiving those services (at least in the most effective way) and abandoning religious education. The title $\mathrm{X}$ regulations increased the cost to the grantee of providing abortion-related services with its own money: the grantee now must build and staff a separate facility, at considerable and (but for the regulations) unnecessary expense. Thus, both cases resemble League of Women Voters. Each goes beyond a mere refusal to fund and conditions government benefits upon a private group's willingness to forgo a constitutionally protected activity funded by its own resources.

Under the free speech clause, the Court has struck a middle ground by upholding spending restrictions that impose a modest inconvenience on the exercise of the right and condemning restrictions with a heavier impact. In League of Women Voters and Taxation with Representation, the ultimate determination of constitutionality depended upon the degree of burden in light of the alternative avenues of expression available. ${ }^{147}$ Applying this approach to Grand Rapids, the Court should have assessed the difficulty of providing comparable educational services at neutral sites, as this is the measure of the burden imposed by restriction (2). The record in the relevant Supreme Court cases showed that between 29 and 42.5 percent of the entire budget for the nonpublic portion of programs of this sort would be consumed by noninstructional costs if the services could not be provided on premises. ${ }^{148}$ Testimony also indicated that off-premises programs

146 Grand Rapids, 473 U.S. at 385.

147 Compare Regan v. Taxation with Representation, 46I U.S. 540, 544-46 (I983) (finding that a tax provision forbidding substantial political lobbying by nonprofit organizations is constitutional because another provision of the tax code permitted such organizations to establish a separate affiliated entity that could engage in lobbying) with FCC v. League of Women Voters, 468 U.S. 364,395 ( 1984 ) (striking down a law forbidding broadcasters from editorializing apparently because it was impossible for such broadcasters to establish a separate affiliated station to present editorials).

148 See Joint Appendix at 360, Grand Rapids (No. 83-990) (reporting effects in Grand Rapids); 
would be pedagogically inferior and would increase problems of safety and nonparticipation. ${ }^{149}$ This degree of burden should be considered excessive.

Under title $\mathrm{X}$, the Court should examine the burden imposed upon grantees by the separate facilities requirement. Although precise statistics are unavailable, undoubtedly a substantial financial cost exists, which, though it falls short of the impossibility in League of Women Voters and probably of the burden in Grand Rapids, surely exceeds the relatively mild inconvenience in Taxation with Representation..$^{150}$ On the other hand, militating in favor of the HHS regulations (albeit not conclusively) is the non-financial dimension of the case. More important to abortion promoters than the economies of unified operations is access to clients who might not go to a facility devoted solely to performing abortions and pro-abortion counseling. Realistically, only those who have decided to obtain an abortion will go to an abortionist, while many who are in doubt (including those who are not yet pregnant) will go to a family planning clinic. By contrast, those attending a religious school presumably have already made their choice. Gathering a wider audience for the counseling of abortion is a significant, and symbolically troublesome, form of assistance. It is almost like allowing governmental programs to be administered at church - after the sermon, of course.

\section{Use of Public Facilities}

There has been extensive litigation for more than forty years over the rights of religious speakers and groups to use public property. In virtually all such cases, the conclusion has been the same: it does not violate the establishment clause to allow religious speakers and groups to use public property on terms comparable to others, and it generally violates the free speech or free exercise clause to forbid it. Thus, in O'Hair v. Andrus, 151 the District of Columbia Circuit held that it was permissible to allow Pope John Paul II to conduct a mass before an audience of approximately half a million on the National Mall. The Catholic Archdiocese agreed to pay "any possible incremental sums ascribable to the Mass as a religious worship,"152 including the building of the platform for the altar, and the expense of fencing, sound

Joint Appendix at 66-67, 68, Aguilar (No. 84-237) (reporting effects in St. Louis and New York).

${ }^{149}$ See Joint Appendix at 35-36, Aguilar (No. 84-237).

150 Compare Massachusetts v. Secretary of Health \& Human Servs., 899 F.2d 53, 72-75 (Ist Cir. 1990) (invalidating the title $\mathrm{X}$ regulation on analogy to League of Women Voters), petition for cert. filed, 59 U.S.L.W. 3037 (U.S. June 8, 1990) (No. 89-1929) with New York v. Sullivan, 889 F.2d 401, 4I2-I4 (2d Cir. 1989) (upholding the title X regulation on analogy to Taxation with Representation), cert. granted, I10 S. Ct. 2559 (1990).

$1516 r_{3}$ F.2d 93I (D.C. Cir. 1979).

152 Id. at 936. 
equipment, electrical facilities, portable toilets, first aid stations, chairs, other physical facilities, over one thousand ushers and guides, and clean-up after the event. ${ }^{153}$ The federal government provided the site, as well as "police, sanitation, and related public services" similar to those provided for other large assemblies in the park. ${ }^{154}$ The court held that to permit the papal mass on those terms was neither aid to nor endorsement of religion. 155

Similarly, in Widmar $v$. Vincent, ${ }^{156}$ the Supreme Court held that it would not violate the establishment clause for a public university to allow a student religious group to meet in university facilities that were uniformly made available to other student groups. ${ }^{157}$ The Court reasoned that an "open forum" of this sort "does not confer any imprimatur of state approval on religious sects or practices."158 Even though the university had a "compelling" interest in complying with its constitutional obligation under the privacy-separation rationale to avoid funding religion, the use of public facilities was not impermissible support. ${ }^{159}$ Indeed, the Court held that absent a compelling countervailing interest, equal access to the university's "open forum" for religious groups was required by the free speech clause. ${ }^{160}$ These are not isolated decisions. There are at least a dozen cases in the Supreme Court alone upholding the right of religious groups and speakers to carry on their activities on public property on terms equal to those imposed on other groups. ${ }^{161}$ No Supreme Court cases are to the contrary.

In the abortion context, however, the Court has reached the opposite conclusion. In Webster, the Court held that a ban on the use of public facilities is indistinguishable from a ban on direct funding. "Having held that the State's refusal to fund abortions does not violate

153 See id. at $933,936$.

154 Id. at 936.

155 See id. at $935-36$.

156454 U.S. 263 ( $198 \mathrm{I}$ ).

157 The Court recently extended its reasoning to high school groups. See Board of Educ. v. Mergens, I Io S. Ct. 2356, 2372-73 (I 990$)$.

158 Widmar, 454 U.S. at 274 .

159 Id. at 271 .

160 See id. at 269.

161 See, e.g., Board of Airport Comm'rs v. Jews for Jesus, Inc., 482 U.S. 569, 575-77 (1987); Heffron v. International Soc'y for Krishna Consciousness, Inc., $45^{2}$ U.S. 640, 652-53 (I98I); Poulos v. New Hampshire, 345 U.S. 395 (r953); Fowler v. Rhode Island, 345 U.S. 67, 69 (I953); Kunz v. New York, 340 U.S. 290, 293 (I95 I); Niemotko v. Maryland, 340 U.S. 268, 272-73 (I95 I); Marsh v. Alabama, 326 U.S. 50r, 504-05 (r946); Largent v. Texas, 3 r8 U.S. 4I8, 422 (I943); Jamison v. Texas, 3r8 U.S. 413, 416-I7 (I943); Cox v. New Hampshire, 3 I2 U.S. 569, 578 (I94I); Schneider v. State (Town of Livingston), 308 U.S. 147, 157-65 (1939); Lovell v. City of Griffin, 303 U.S. 444, 45I (1938). See generally Laycock, Equal Access and Moments of Silence: The Equal Status of Religious Speech by Private Speakers, 8I Nw. U.L. REV. I, 9-35 (Ig86). 
Roe v. Wade," the Court said, "it strains logic to reach a contrary result for the use of public facilities and employees."162 It is difficult to see how the Court could reach such a conclusion in the face of cases like O'Hair and Widmar, which prohibit direct funding of religion but require equal access to public facilities.

Providing access to public property is different from direct funding, for precisely the reason that differentiates penalties from mere refusals to subsidize. A religious group or an abortionist who uses public property for purposes compatible with its ordinary use does not impose any additional costs on the public. ${ }^{163}$ In Webster, for example, the evidence showed that the patient paid "all of the public facility's costs in providing [the] abortion."'164 However, if the public property had been off limits, the patient's cost would have exceeded the cost of the abortion itself (because of the need to travel and related complications, which could far exceed the cost of the abortion alone). Therefore, under the analysis of Part I, a ban from access to public facilities is unconstitutional because it is more than a mere refusal to fund.

Moreover, it is not true, as the Court assumed in Webster, that the refusal to allow abortions in public facilities "leaves a pregnant woman with the same choices as if the State had chosen not to operate any public hospitals at all."165 If the state had so chosen, there would be more private hospitals at which abortions might be more readily available. By the same token, if the state had chosen not to operate any public schools, there would surely be more private schools, including more religious schools. In the extreme case, if all hospitals were public, the ban on abortions in public facilities would be equivalent to a direct prohibition of all abortions that must be performed in a hospital. The Webster Court conceded that "[a] different analysis might apply if a particular State had socialized medicine and all of its hospitals and physicians were publicly funded,"166 but it failed to recognize that partially socialized medicine has a similar, if less extreme, effect. ${ }^{167}$

162 Webster v. Reproductive Health Servs., rog S. Ct. 3040, 3052 (1989) (plurality opinion).

163 The same is not true for public employees who perform an abortion. The public employee imposes a marginal cost on the public and uses time which could have been used for other medical assistance.

164 Webster, 109 S. Ct. at 3052 (quoting Reproductive Health Serv. v. Webster, 85 I F.2d 107r, 1083 (8th Cir. I988)). This assumes that the hospital is not full. If it is full, the performance of the abortion would displace another medical procedure, which would impose a marginal cost.

165 Id.

166 Id. at 3052 n.8; cf. Giannella, Religious Liberty, Nonestablishment, and Doctrinal Development, 8I HARV. L. REV. 513, 522-23 (I968) (arguing that in a collectivist state, which owns and controls all resources, government "aid" to religion would be constitutionally required).

167 The issue may also be compared to the "state action" doctrine under the fourteenth 


\section{Alternative Understandings of the Underlying Rights}

The privacy-separation rationale of Roe and Lemon is not the only, and may not be the best, understanding of the rights to choose abortion and religious education. Two prominent alternatives are, first, the "anti-coercion" rationale, which holds that although the government may not use force or compulsion, it may use less coercive means to induce individuals to adopt the socially preferred choices of childbirth and public education, and, second, the "relational rights" or "equal protection" rationale, which holds that abortion rights and religious freedom uphold systemic (and not merely individual) values related to nonsubordination. The question is whether these alternative rationales for the underlying rights require modifications in the analysis of the funding issue.

\section{A. The Anti-Coercion Rationale}

In Maher and Harris, the Court justified bans on abortion funding on the ground that "the constitutional freedom recognized in $[R o e]$ and its progeny ... . did not prevent [the state] from making 'a value judgment favoring childbirth over abortion, and . . . implement[ing] that judgment by the allocation of public funds."'168 The Court must have meant that the government's interest in protecting unborn life is legitimate, but limited to non-coercive means. Although this conception is inconsistent with the privacy-separation rationale, ${ }^{169}$ it is a plausible alternative understanding of the abortion right.

Indeed, the anti-coercion rationale provides a more persuasive reading of the precedents that supported Roe. One of the many similarities in the debates over abortion and parochial schools is that both rights trace their origin to the Supreme Court's famous I925

amendment, where "liberal" Justices and commentators have tended to conclude more readily that various contacts between the government and ostensibly private institutions (financial assistance, presence on government property, and the like) require the attribution of private decisions to the government. See, e.g., Blum v. Yaretsky, 457 U.S. 991, 1027-29 (1982) (Brennan, J., dissenting); Jackson v. Metropolitan Edison Co., 4I9 U.S. 345, 362 (1974) (Douglas, J., dissenting); id. at 366-73 (Marshall, J., dissenting); Burton v. Wilmington Parking Auth., 365 U.S. 7I5, 721-26 (196I). Thus, there is irony in Justice Blackmun's complaint in Webster, joined by Justices Brennan and Marshall, that:

by defining "public facility" as "any public institution, public facility, public equipment, or any physical asset owned, leased, or controlled by this state or any agency of political subdivision thereof,"... the Missouri statute prohibits the performance of abortions in institutions that in all pertinent respects are private, yet are located on property owned, leased, or controlled by the government.

I09 S. Ct. at 3068 n.I (Blackmun, J., concurring in part and dissenting in part) (quoting Mo. REV. STAT. \$ I88.200 (Ig86)).

168 Harris, 448 U.S. at 3 I4 (quoting Maher v. Roe, 432 U.S. 464,474 (I977)); see also

Webster, rog S. Ct. at 3052 .

${ }^{169}$ See supra pp. I000-0I. 
decision, Pierce v. Society of Sisters. ${ }^{170}$ Pierce held unconstitutional a state law requiring all parents to send their school-age children to public schools on pain of criminal sanction for refusal. "The fundamental theory of liberty upon which all governments in this Union repose," according to the Court, "excludes any general power of the State to standardize its children by forcing them to accept instruction from public teachers only."171 Pierce, in turn, relied on Meyer $v$. Nebraska, ${ }^{172}$ in which the Court struck down a state law making it criminal for anyone to teach modern languages other than English to children who had not passed the eighth grade. Pierce and Meyer are the charter of rights for those who prefer to send their children to private, including religious, schools and (within limits) to control the content of their curriculum. ${ }^{173}$ While these decisions were originally grounded in concerns about creation of a public orthodoxy (a concern that now sounds in the first amendment rights of free speech and religious freedom), more recently these decisions have been cited in support of the broader claim of a right to autonomy in matters of marriage, procreation, child-rearing, and family life - and thus as the precedential pillars of Roe $v$. Wade. ${ }^{174}$

The conception of rights in Pierce and Meyer, however, is different from the privacy rationale of Roe. As discussed in Part $I, 175$ Roe was predicated on the government's lack of authority to resolve a question of deep personal importance and public disagreement: the moral-legal status of a being between conception and viability. Pierce and Meyer, by contrast, were predicated on limits to the use of governmental force, even when deployed to promote objectives within the government's legitimate authority.

Meyer is most explicit on this point. Nebraska's objective in prohibiting instruction of children in foreign languages was to promote the English language and American ideals of citizenship. ${ }^{176}$ In striking down the Nebraska statute, the Supreme Court did not suggest that these purposes are "private" matters, outside the proper domain of the state. Instead, the Court held that "a desirable end cannot be promoted by prohibited means."177 Although the government could pursue its objectives by other means (including its control over the cur-

$170{ }_{268}$ U.S. 510 (1925).

$171 \mathrm{Id}$. at 535 .

172262 U.S. 390 (1923).

${ }_{173}$ See Arons, The Separation of School and State: Pierce Reconsidered, 46 HaRv. Educ. REv. 76, 77 (1976) (discussing the centrality of Pierce).

174 See Roe v. Wade, 4 IO U.S. II3, 153 (1973) (citing Pierce and Meyer as protecting "child rearing and education"); id. at I69 (Stewart, J., concurring) (citing Pierce and Meyer as protecting "personal choice in matters of marriage and family life").

175 See supra pp. 994-96.

176 See Meyer, 262 U.S. at 40 .

177 Id. 
riculum of public schools), ${ }^{178}$ the Meyer Court forbade the use of the ultimate governmental weapon of coercion: "Perhaps it would be highly advantageous if all had ready understanding of our ordinary speech, but this cannot be coerced by methods which conflict with the Constitution."179

An anti-coercion understanding of constitutional rights is not uncommon in cases involving a clash of opinions. In West Virginia State Board of Education v. Barnette, ${ }^{180}$ the Supreme Court held that the state may not punish schoolchildren for refusing to join the flag salute. This did not mean, however, that the state was prohibited from encouraging the flag salute and the values it represents. Similarly, in the most recent flag-burning decision, United States $v$. Eichman, ${ }^{181}$ Justice Brennan distinguished between "creat[ing] national symbols, promot[ing] them, and encourag[ing] their respectful treatment," and "criminally proscribing expressive conduct because of its likely communicative impact." 182

Under the anti-coercion rationale, there can be no constitutional objection if the government funds public schools but not private religious schools. As Professor Cass Sunstein has observed, if the present law on private school funding is correct, it is because the right recognized in Pierce "is not a right to government neutrality in general or in the abstract, but instead merely a right to be free from criminal coercion in the private education of one's children."183 Under the Pierce anti-coercion conception, there is no constitutional impediment to a governmental policy that makes a "value judgment" in favor of public over private schools. ${ }^{184}$ The government is entitled to encourage matriculation at public schools and discourage it at private schools, just as the government may encourage the learning and use of English and discourage foreign language education. One permissible way to do so is to subsidize one and not the other.

A similar anti-coercion construction can be applied to the abortion right. ${ }^{185}$ Much of the passion of the pro-choice position stems from

178 See id. at 402 (referring approvingly to "the State's power to prescribe a curriculum for institutions which it supports").

179 Id. at 40 .

1803 I9 U.S. 624 (r943).

181 I IO S. Ct. 2404 (I990).

182 Id. at 2409; see also Gilbert v. Minnesota, 254 U.S. 325, 336-37 (I920) (Brandeis, J., dissenting) (arguing that government may not prohibit the teaching of pacifism, although it has the authority to promote the contrary view).

183 Sunstein, supra note 62 , at $34 \mathrm{I}$.

${ }^{184}$ Cf. Harris, 448 U.S. at ${ }^{1} 4$ (stating that the state may prefer childbirth over abortion).

185 Professor Michael Perry's well-known article arguing that the Supreme Court was "plainly wrong" in the Hyde Amendment case, see Perry, supra note 24, appears to be predicated on the judgment that $R o e$ limits governmental ends rather than governmental means:

Once one concedes to government the authority to take action - any action (including a refusal to subsidize abortion), whether or not "unduly burdensome" - predicated on 
a perception that anti-abortion laws force women to perform an arduous and intrusive service against their will. The most powerful analogy is to enslavement. ${ }^{186}$ The point is not that preserving unborn life is an improper governmental purpose, but that the government cannot force women to bear the burden of pregnancy in order to achieve that purpose. In $A$ Defense of Abortion, 187 Judith Jarvis Thomson analogized anti-abortion laws to kidnapping a person for nine months in order to sustain the life of a famous violinist. There appears to be no quarrel with the proposition that the government could legitimately assist the violinist and use tax monies for that purpose; it could hire someone to perform the necessary services. The argument is only that the government cannot dragoon individuals against their will. ${ }^{188}$ It follows from this conception of the abortion right that the government may take steps short of legal compulsion to protect unborn life. ${ }^{189}$

An anti-coercion rationale for the abortion right would, like the privacy rationale, prevent the government from criminalizing the performance of abortions. But it would permit the government to take various steps to encourage women to eschew abortion - either by taking more effective precautions to avoid pregnancy or by carrying their fetuses to term. Among the more obvious steps in such a strategy would be public education about embryological development; focused counseling for women contemplating abortion (including accurate information about fetal development and about public and private re-

the view that abortion is per se morally objectionable, it necessarily follows . . . that a woman's interest in terminating her pregnancy is not only less weighty than government's interest in preventing abortion, but that it is not constitutionally protected at all - that it has no constitutional status.

Id. at III7-I8 (emphasis in original). Professor Perry does not explain from whence this principle derives, though his analogies to other constitutional areas, including free speech, see id. at II 18-20, suggest that it is not a peculiarity of Roe. Unless the examples I have discussed (Pierce, Meyer, Eichman, Bob Jones) were wrongly decided, it is simply not true that the government necessarily lacks the power to attempt in non-coercive ways to discourage constitutionally protected behavior that the government views as immoral, unpatriotic, distasteful, or unhealthy. It would not follow, for example, that just because "hate speech" is constitutionally protected, a public university would be foreclosed from taking "action - any action" to discourage it. Without this unsupportable assumption, Perry's argument fails.

${ }^{186} \mathrm{See}$, e.g., Webster v. Reproductive Health Servs., I09 S. Ct. 3040, 3077 (I989) (Blackmun, J., concurring in part and dissenting in part) (describing anti-abortion legislation as "conscript[ing] a woman's body"); Tribe, supra note 27 , at 337 (suggesting there is a "strong parallel between a woman's right not to remain pregnant and every person's inalienable right not to be enslaved").

187 Thomson, A Defense of Abortion, x PHIL. \& PUB. AFF. 47 (1971).

188 See Regan, Rewriting Roe v. Wade, 77 Mich. L. REv. 1569, I571-I6ro (I979) (applying good samaritan law to the abortion context).

189 Indeed, Professor Tribe devotes a section of his article against Harris to the proposition that the government should (and may have a constitutional duty to) protect the unborn in ways that do not invade the freedom of their mothers. See Tribe, supro note 27, at 340-43. 
sources available to assist them and their babies); ${ }^{190}$ reasonable waiting periods; 191 improved public and private support for pregnant women and infants (medical care, nutrition, housing, education, and other necessary services); greater publicity about the ease of adoption (including a public commitment to care for unwanted infants without exception); consumer-oriented regulation of abortion providers to guard against misrepresentation and misinformation; measures to guard against pro-abortion coercion by husbands, boyfriends, parents, and others who exercise power over the pregnant woman; better enforcement of paternal child support obligations; and clear articulation of the moral principle that abortion is not an acceptable means of birth control. And, of course, the state would pay the full cost of childbirth for those who could not afford it, but abortion costs would not be paid (except where the mother's life was endangered or in the case of another appropriate exception). In short, abortion could be treated as a personally and socially destructive activity, to be discouraged though not banned.

Under an anti-coercion rationale, the government's refusal to fund abortions or private religious schools is unobjectionable, because the underlying rights have to do with unconstitutional means (coercion) rather than the ends that government can pursue. Thus, under this conception both Harris and Lemon were rightly decided. ${ }^{192}$

\section{B. The Relational Rights or Equal Protection Rationale}

Recent constitutional scholarship has tended to move away from the privacy rationale for Roe and toward theories grounded in equal protection. The critical fact, according to this view, is that pregnancy is a burden on the woman's ability to pursue an equal and autonomous economic and social life and a principal cause of the subordination and dependency of women. Given the technical feasibility of abortion, it is said that pregnancy-related disabilities are no longer "natural"; with a right to abortion, women are able, albeit at some physical, psychological, and financial cost, to avoid the burdens of childbirth and child-rearing. Their situation therefore becomes closer to a man's. Laws forbidding abortion, then, are a form of legally imposed inequality and subordination. They protect the privileged position of men and deny women the right they would otherwise have to control their bodies and make choices about their futures. ${ }^{193}$

190 This would require reconsideration of portions of City of Akron v. Akron Center for Reproductive Health, Inc., 462 U.S. 416, 443-44 (x983).

191 Likewise, this would require reconsideration of Akron. See id. at 449-51.

192 That is, Lemon's implicit rejection of the free exercise claim was right; the anti-coercion rationale does not support the establishment clause holding in the case.

193 For elaboration of this equal protection approach to abortion rights, see, for example, $C$. MacKInnon, FEminism UNmOdified 93-IO2 (I987); L. TRIBE, supra note 22, § 15-ro, at 
This conception of the abortion right provides a stronger basis for the claim that the Hyde Amendment is unconstitutional because it is not predicated on the government's noninvolvement in a "private" matter. This approach has taken two forms: the "relational rights" argument and a more doctrinally orthodox equal protection argument. This section will consider these views and their analogous use in the religious school context.

I. Relational Rights. - The relational rights argument has been most fully developed by Professor Laurence Tribe. 194 Tribe distinguishes between rights that are individual, alienable, and negative and rights that "correspond to systemic norms - norms concerned with structuring power relationships to avoid the creation or perpetuation of hierarchy in which some perennially dominate others."195 These "relational" rights, he explains, are necessarily inalienable. Because individuals are "not their sole focus," individuals have no right to waive them. ${ }^{196}$ And because these rights are not waivable, it follows that an individual's failure to summon forth the material resources necessary for their exercise cannot be a ground for waiver: the failure of the government to provide the aid necessary to exercise the right "amounts to enforced alienation of the underlying right."197 Therefore, Tribe concludes, "government must be recognized as having an affirmative duty to protect such rights from the distortions of a purely private market - to lift them beyond the status of commodities that individuals may freely buy and sell provided they have acquired and retained the necessary wealth."198

Professor Tribe's argument proves too much. Virtually every if not every - right protected by the Constitution has a "relational" or "systemic" dimension. Freedom of the press, for example, exists at least as much for the purpose of protecting our democratic institutions as it does for the private interests of the barons of the press. And it might well be that the right is inalienable (to the government, that is). Perhaps it is unconstitutional for the government to buy a newspaper in order to suppress its views, but it does not follow that the government's refusal to subsidize newspapers "amounts to enforced alienation of the underlying right" or that there is any "affirmative

I353-56; Ginsburg, Some Thoughts on Autonomy and Equality in Relation to Roe v. Wade, 63 N.C.L. REv. 375, 382-86 (1985); Karst, The Supreme Court, r976 Term - Foreword: Equal Citizenship Under the Fourteenth Amendment, 91 HARV. L, REv. I, 57-59 (1977); Law, Rethinking Sex and the Constitution, 132 U. PA. L. REv. 955, 1016-28 (1984); and Olsen, The Supreme Court, 1988 Term - Comment: Unraveling Compromise, I03 HARV. L. REV. I05, II726 (1989).

194 See Tribe, supra note 27 , at $330-35$.

195 Id. at $332-33$.

196 Id. at 333 .

197 Id.

198 Id. at $333-34$. 
duty" on the part of the government to pay for its exercise. Indeed, no example beyond that in this Article is necessary to expose the weakness in Professor Tribe's position. He states, and I agree, that along with much of the Constitution, the establishment clause "can be viewed as resting on relational norms and on the need for deliberate diffusion of power to combat the hegemony of any single group or faction."199 The establishment clause forbids governmental action with the primary effect of advancing or inhibiting religion. But even Tribe denies that this right, "relational" though it may be, entails an "affirmative duty" on the part of government to subsidize its exercise for those who cannot afford it. ${ }^{200}$ The problem is that Tribe provides no basis for distinguishing between relational rights that $d o$ require funding and relational rights that do not require funding.

2. Equal Protection. - It is more persuasive to cast the abortion right in standard equal protection terms. The reason for heightened judicial scrutiny of abortion laws, according to this theory, is not that those laws invade "privacy" rights, but that they are directed exclusively at women, giving rise to the apprehension that they may reflect a conscious or unconscious bias against women or in favor of the subordination of women. If so, laws refusing to fund abortions are subject to heightened scrutiny for precisely the same reason - they directly affect women only.

This equal protection rationale, if accepted, would provide a stronger basis for claiming a constitutional right to funding of abortions under Medicaid than is provided by the privacy-separation rationale. As discussed in Part $I,{ }^{201}$ the privacy rationale provides the justification for the refusal to fund: the government must be agnostic about abortion in the face of national dissension. The equal protection rationale for strict scrutiny of anti-abortion laws, on the other hand, is fully consistent with strict scrutiny of laws like the Hyde Amendment.

Nonetheless, the argument against Harris under the equal protection rationale, while more plausible, remains problematic. First, it is not clear that established equal protection doctrine truly supports a theory of abortion rights. To be sure, the immediate impact of a proscription on abortion falls only on women. But the effects on men are substantial as well. Having a child changes a man's life as well as a woman's. Both married and unmarried men have been known to resist the responsibilities of unintended fatherhood. Abortion is often their most convenient "out." Indeed, I suspect that in a not

199 Id. at 333 n.I4.

200 See id. at $333-34$ \& n. $x_{5}$.

201 See supra pp. roo6-ri. 
insignificant number of cases it is the man, more than the woman, who feels threatened by the advent of a child and is more likely to view the fetus as an inconvenient abstraction rather than as a baby. This may help to explain why, in polling data, men consistently support abortion rights in somewhat larger numbers than do women. 202

Thus, abortion regulations do not present the classic case for strict scrutiny, where the dominant majority benefits at the expense of a minority. Anti-abortion laws are contrary to the immediate interests of both men and women. Whatever else may be said about them, anti-abortion laws serve no one's selfish interest; they extend protection to a class of helpless third parties, the unborn, at the expense of those in power, both men and women. Indeed, to the extent that equal protection theory asks the legal system to be especially alert to the interests of the weaker, more vulnerable, politically unrepresented members of society, it should cut against abortion rights, because the unborn meet that description far more clearly than any other protected class.

Moreover, even if the class of persons disadvantaged by antiabortion laws were exclusively female, that would not be sufficient under established equal protection doctrine to trigger strict scrutiny. In Geduldig v. Aiello, ${ }^{203}$ for example, the Court held that the failure of a state's disability insurance plan to cover costs associated with pregnancy and childbirth did not discriminate against women in violation of the equal protection clause. While the majority's argument was not particularly persuasive, the result could be correct. When the government is legislating with respect to a matter otherwise within its cognizance through the use of classifications naturally and inextricably tied to racial or sexual differences, there is no entirely satisfactory way to determine whether the classification is discriminatory. For example, rape laws apply by their nature almost exclusively to males, but this does not make those laws constitutionally suspect.

The best one can do in these cases is to engage in speculative counterfactuals: for example, would pregnancy be included in the benefit package if men got pregnant?204 The restriction in Geduldig would likely fail this test. There are differences between pregnancy and other disabilities (pregnancy is generally a matter of choice; other disabilities are not), but those differences are not so overwhelming as

${ }^{202}$ See H. Rodman, B. Sarvis \& J. Bonar, The Abortion Question I4I-43 (1987). For corroborating data, see the National Opinion Research Center of the University of Chicago, General Social Survey cumulative data file (1972-1989).

${ }^{203} 4 \times 7$ U.S. 484 (1974).

204 See Strauss, Discriminatory Intent and the Taming of Brown, 56 U. CHI. L. REv. 935, 993 (1989). 
to dispel the suspicion that an indifference to a condition unique to women may have been a strong motivating factor. ${ }^{205}$

Putting aside the burden that unintended parenthood places on males, the Hyde Amendment raises the same question as the failure to include pregnancy in the disability benefits program: the direct and immediate impact falls exclusively on females. But as in Geduldig, this does not end the analysis. We must engage in a speculative counterfactual: would abortion be treated in the same way if men became pregnant? A negative answer to this seems to be an article of faith among the pro-choice movement ("if men got pregnant, abortion would be a sacrament"); but this overlooks the fact that women, who do get pregnant, are more - not less - likely than men to support restrictions on abortion. ${ }^{206}$ The predominant purpose of modern abortion restrictions is to protect unborn life. We cannot convincingly attribute this commitment (questionable though it may be on other grounds) to a purpose of subordinating women. Given the inconvenience (albeit unequal) of unintended parenthood to both men and women, it is inconceivable that even the most sexist of legislatures would pass an anti-abortion law if it were not for a good faith concern for fetal life.

This is not to deny that a variety of factors influence attitudes toward abortion. For some, these include the belief that motherhood is a natural and important part of a woman's life and that elevation of abortion to a constitutional right is an assault on that understanding. But if public policies could be adjudged guilty by association, it is not obvious that support for abortion funding would survive constitutional scrutiny any more easily than would opposition to it. Some middle-class Americans support abortion, and especially Medicaid funding of abortion, as a way to decrease the number of poor and minority children born into the world and thus to reduce the cost of welfare and the incidence of crime. Some males support abortion rights because of their perception that women should be sexually available, with no attendant commitment on their part. ${ }^{207} \mathrm{As} \mathrm{Ca-}$ tharine MacKinnon has pointed out, the two causes most heavily supported by the Playboy Foundation are abortion rights and opposition to pornography laws. ${ }^{208}$ And some supporters of women's rights

205 Congress reversed the result in Geduldig by passing the Pregnancy Discrimination Act of 1978, Pub. L. No. 95-555, 92 Stat. 2076 (codified at 42 U.S.C. 2000 (k) (r988)).

${ }^{205}$ See supra p. $104 \mathrm{r}$.

207 Professor Catharine MacKinnon has observed:

Under conditions in which women do not control access to our sexuality, [abortion] facilitates women's heterosexual availability. In other words, under conditions of gender inequality, sexual liberation in this sense does not free women, it frees male sexual aggression. The availability of abortion thus removes the one remaining legitimized reason that women have had for refusing sex besides the headache. As Andrea Dworkin puts it, analyzing male ideology on abortion: "Getting laid was at stake."

MacKinnon, supra note 53, at $5 \pi$ (quoting A. Dworkin, Right Wing Women 98-99 (rg83)). ${ }^{208}$ See id. 
are among the ranks of the pro-lifers ${ }^{209}$ (a popular bumper-sticker reads "Equal Rights for Unborn Women"). The constitutionality of abortion funding restrictions should not be decided on the basis of the purity of attitude to be found among the contending forces. It is more charitable - and also more accurate - to accept at face value the predominant concern of both sides, whether that concern is for the rights of women or for the lives of the unborn.

Moreover, even if we conclude that the equal protection theory provides a superior doctrinal rationale for the abortion right itself, it does not necessarily support the right to funding. Even straightforward, facial discrimination is justifiable upon sufficient showing of governmental necessity. The governmental interest supported by the Hyde Amendment is to ensure that taxpayers who conscientiously believe that abortion is the taking of innocent human life are not coerced into paying for it. Nothing in the equal protection rationale casts doubt on the strength or legitimacy of that interest.

The parallel argument in the religious context would be a theory of the religion clauses under which the first amendment is designed for the special protection of minority religions. ${ }^{210}$ In the same way that feminist theories of equal protection are based at times on the need to permit women to participate fully and equally in spheres of life previously reserved to men and at times on the need to recognize the equal importance of women's distinctive needs and perspectives, ${ }^{211}$ minority religious groups at times focus on the right to full participation as equal citizens in public life and at times on the need to maintain an identity separate and distinct from the majority.

It is no accident that religious school systems have been developed by minority religious groups who feel threatened by the prevailing ideology (once Protestant, now secularist) of the public schools. These separate school systems have been an important means for maintaining religious identity and avoiding an unwelcome assimilation, while still developing the skills necessary for participation in modern American life. Parochial schools have been the creation of the minority and their refuge from majoritarianism. Lemon, like its popularly adopted precursors in many state constitutions forbidding aid to religious schools, protects the majority at the expense of the minority. The majority gets the schools that it wants, using tax dollars extracted from everyone; minority religious groups are forced to support the majority's school systems and also to pay for their own. If the purpose

209 See Callahan, Value Choices in Abortion, in ABortron: UNDERSTANDING DIFFERENCES 285 (S. Callahan \& D. Callahan eds. 1984); Amicus Curiae Brief of Feminists for Life of America, Webster (No. 88-605).

210 See Developments in the Law - Religion and the State, roo HARv. L. Rev. I607, I648 n.38 (1987) (comparing feminist jurisprudence to a focus on minority religions under the first amendment).

211 For a review and assessment of these strands of feminist equal protection theory, see Becker, Prince Charming: Abstract Equality, I987 Sup. CT. REv. 201, 228-37. 
of the religion clauses is to protect the position of minority faiths to prevent their forced assimilation and their exploitation at the hands of the majority - Lemon is not simply unsupportable but perverse.

Moreover, a much stronger argument can be made that denial of funding to private religious schools is the result of purposeful discrimination against minority religions. The historical evidence is powerful that the public school movement of the nineteenth and early twentieth centuries was a self-conscious attempt to spread Protestant values among the people, especially among immigrant groups with different religious backgrounds. ${ }^{212}$ Although the religious intentions of the movement are rarely acknowledged today, at the time these were addressed openly. Typical was this comment by Horace Mann, the leader of the movement:

All those who are worthily laboring to promote the cause of education are laboring to elevate mankind into the upper and purer regions of civilization, Christianity, and the worship of the true God; all those who are obstructing the progress of this cause are impelling the race backwards into barbarism and idolatry. 213

Protestantism was popularly associated with Americanism, and Catholicism was widely considered to be anti-democratic, disloyal, degraded, superstitious, and generally "un-American." 14 This manifested itself in two ways. First, the public school system was imbued

212 See C. Glenn, The Myth of the Common School 146-78, 205-06 (Ig88); C. Kaesthe, Pillars of the Republic: CoMmon Schools and AMERICAN Society, r780-1860, at 75-I03 (I983); J. SaRna, American Jews and Church-State Relations i8-25 (ig89); see also Lott, An Explanation for Public Provision of Schooling: The Importance of Indoctrination, 33 J.L. \& ECON. I99 (1990) (arguing that indoctrination is the primary purpose of public education).

213 Common School J., Jan. I, I846, at I5 (authored by Horace Mann), quoted in C. GLENN, supra note $2 \mathrm{I2}$, at $\mathrm{I} 7 \mathrm{I}-72$. While opposing introduction of what he called "sectarian instruction or sectarian books" into the public schools, H. MANN, FOURTH ANNUAL REPORT OF THE SECRETARY OF THE BOARD 59 (1841), quoted in C. GleNN, supra note 212, at 164, Mann claimed that "[m]oral training, or the application of religious principles to the duties of life," should be the "inseparable accompaniment" to education. H. MANN, NINTH ANNUAL REPORT OF THE SECRETARY OF THE BOARD I57 (1846), quoted in C. GLENN, supra note 212, at 165. "Nonsectarian" religious education "was in reality nondenominational Protestantism." D. RAVITCh, The Great School WarS 9 (I974); accord C. GLENN, supra note 212 , at 132.

214 The virulence of anti-Catholic feeling during this period is difficult for a person of today to imagine. For historical accounts, see S. AHISTROM, A RELIGIOUS History of THE AMERican People 558-63, 852-54 (I972); R. Billington, The Protestant Crusade i800-i860, at 345-79 (I938); and M. Schwartz, The Persistent Prejudice: Anti-Catholicism in AMERICA 38-IOI (r984). Prominent works contending that Catholicism is antithetical to American values include L. BeEcher, PleA FOR The West 66-68 ( 1835 ); J. STrong, Our Country: Its Possible Future and Its Present Crisis 46-59 (1885); and R. Thompson, The Papacy AND THE CIVIL POWER 56-59 (I876). The anti-Catholic political movement included such notables as Presidents Grant and Hayes and presidential candidate James G. Blaine, all of whom made denial of funding to parochial schools a major part of their political programs. See D. Ravitch, supra note 2 I3; M. SCHWARTZ, supra, at 66-70. 
with Protestant values, including prayers, Bible readings from the King James version, and overt religious teachings. ${ }^{215}$ Second, socalled "sectarian" (meaning Catholic) schools were discouraged, denied any share in public funding, and even outlawed. ${ }^{216}$ Selective funding was part and parcel of Protestant hegemonism in nineteenth and early twentieth century America.

It does not necessarily follow, however, that there is a judicially enforceable constitutional right to public funding today. It would be difficult to prove that the government's only reason for continuing to refuse to fund religious schools is to induce religious assimilation and homogenization. Indeed, a more important reason is that the courts have told them such funding would be unconstitutional. There are also plausible reasons, unrelated to hostility to religion, that persuade some persons of good will that public schools are superior to private schools, including private religious schools. ${ }^{217}$ The discriminatory origins of the anti-funding position do not necessarily vitiate legitimate reasons for keeping it in place. ${ }^{218}$ Moreover, the federal courts should be reluctant to order so sweeping a modification in so important and long-standing a public institution as the public school system, ${ }^{219}$ although this does not diminish the constitutional responsibility of state legislatures to correct their policies.

The reluctance to achieve change through judicial intervention in this area should be especially strong because the underlying constitutional theory - that the religion clauses should be interpreted to protect the position of minority religions - is so indeterminate. There are many claims upon governmental resources that would facilitate the survival and flourishing of minority religions, many of whose members are less affluent than the majority. But it is hard to believe that the free exercise clause is simply an entitlement to government funding of whatever religious activities minority faiths might desire.

215 See C. Mooney, Boundaries Dimly Perceived: Law, Religion, Education, and THE COMMON GOOD 52 (I990) (“[Public schools] represented not a secularizing influence but a patriotic and civilizing influence, into which the Protestants who controlled them could inject the teachings, practices, and especially the morality of the mainline churches."); Dolan, Freedom of Religion and American Catholicism, in FREEDOM OF RELIGION IN AMERICA 67, 68 (H. Clark ed. 1982) ("Highly moral in purpose and visibly religious in practice, public education was schooling in a sectarian Protestant value system."); see also C. GLENN, supra note $2 \times 2$, at 14678 (discussing the influence of Protestant beliefs and practices over public education); J. SARNA, supra note 212 , at 18-25 (same).

216 See C. GlenN, supra note 212 , at $219-34$; J. Higham, Strangers in the LaNd: PatTerns of AMERICAN NATIvisM 1860-I 925, at 28-29, 59-60 (1955). The laws struck down in Pierce and Meyer were products of this movement.

217 See supra p. Ior3.

${ }^{218}$ Cf. McGowan v. Maryland, 366 U.S. 420, 444 (196r) (upholding Sunday closing laws on the ground that they now have secular justifications even though their origins were religious).

219 See generally R. NAGEL, Constitutional Cultures 22-26 (1989) (defending a restrained judicial role). 
The feminist equal protection theory and the "minority religions" theory of the first amendment share an analytical weakness: neither provides sufficient guidance about the contours of constitutional rights. Both theories provide useful insight and perspective into the purpose of constitutional doctrine, but neither tells the judge what is forbidden or what is required. These theories provide more of a political program than a "satisfactory and workable general standard to be applied by judges."220 It cannot be true that the Constitution requires all actions that benefit (most) women and forbids whatever disadvantages them. The same goes for the needs and desires of minority religions. In the end, these theories can help account for the constitutional protections, but they need to be supplemented with more concrete doctrines. They do not, then, provide a compelling basis for rejecting Harris or Lemon, even if they provide reasons for disquietude with the results.

\section{Toward an Analysis of Selective Funding}

Two distinct bases for challenging selective funding have emerged from the preceding discussion of abortions and parochial schools. First, a government program may be unconstitutional if it funds a substitute for a constitutionally protected choice without also funding the individual's preferred choice. Only if there is a plausible basis for the selective funding, predicated on a reason that is not objectively hostile to the right in question (that is, a reason that can be accepted, in principle, even by supporters of the right), is it permissible for the government to fund one choice but not the other.

The corollary of this principle is that the government is under no obligation to fund a constitutionally protected activity merely because it funds other activities, if those other activities are either complements to, or unrelated to, the constitutionally protected right. Only if the constitutional right involves the freedom to choose between two or more alternatives will this principle have any application. There is no obligation to fund abortions merely because the government funds heart transplants or flu vaccinations, or religion classes merely because the government funds English and math. But there is a presumptive obligation to fund abortions when the government funds childbirth, and to fund religious schools when it funds secular schools, unless there is a plausible, non-hostile reason for the selective funding. In the case of abortion, I believe there is such a reason: providing medical assistance at childbirth is important to the health and safety of the newborn infant, a purpose with which we all agree. In the case of

220 Becker, supra note $2 \mathrm{II}$, at 247 ; see also C. MACKINNoN, supra note I93, at 40 (arguing that the "task [of the feminist analysis] is not to formulate abstract standards that will produce determinate outcomes in particular cases"). 
religious schools there may be such a reason, albeit somewhat tenuous: that public schools may in some instances be more economically, socially, racially, and ideologically diverse than private schools, and that this diversity is an important aspect of training for citizenship in a pluralistic United States.

The second basis for objecting to selective government funding applies when the government goes beyond a refusal to pay the costs of exercising a constitutional right and imposes an additional loss on those exercising the right. A series of Supreme Court cases demonstrates that the government need not subsidize an individual's free speech, but it cannot deprive him of valuable benefits merely because he has spoken. By the same token, the government could not deny all Medicaid benefits to a woman who procures an abortion, even though it need not pay the cost of the abortion itself. And the government should not be able to deny all education funding to families who seek a religious component in their children's education, even though it need not (and, under the establishment clause, may not) pay the incremental cost of the religious component itself.

These two approaches establish only a prima facie case for challenging the selective funding. The government may still prevail if it has a legitimate (perhaps compelling) purpose unrelated to hostility to the right. In the abortion and school funding contexts, the principal governmental interest is to protect the rights of those who consider it a violation of conscience to support either abortions or religious training. The consequence of this interest, however, is different in the two contexts. The Hyde Amendment is narrowly drawn to accomplish the purpose of ensuring that unwilling taxpayers are not forced to pay for abortions, but Lemon is vastly overbroad. Under Lemon, the state not only refuses to pay for religious training; it also refuses to pay for secular education for students who want to add a religious element at their own expense.

Analysis of selective funding programs thus requires both an intensive inquiry into the nature of the constitutional rights involved, including the government's countervailing interests, if any, and a general theory that identifies when rights are threatened by selective funding. In this Article I have attempted to provide both: a careful consideration of the basis for abortion rights and the right to choose religious schools, with alternative rationales, and a general theory of selective funding. Neither element is dispensable. A general theory of funding does not, and cannot, tell us the contours of the constitutional right; and an understanding of the nature of the right does not reveal when the refusal to fund is permissible or impermissible.

Some commentators have contended that there is no general doctrine of unconstitutional conditions that can help in these cases. ${ }^{221}$ To

221 See, e.g., Marshall, supra note 28 , at 244; Sunstein, supra note 2I, at 609-10, 615-20; Sunstein, supra note 62 , at 339-44. 
the extent they remind us that the general doctrine is insufficient in itself - that it does not eliminate the need for a particular analysis of the constitutional rights involved - they are correct. As this Article has shown, viewing the abortion right as a privacy right carries one implication for funding issues; viewing it as an anti-coercion or equal protection right has different implications. The same is true of religious schools. But to say that a general theory plays no part is to deny that similarly conceived rights must be treated in the same way and to allow judges who favor educational choice and oppose abortion rights to go one way and judges who favor abortion rights and oppose educational choice to go the other.

Professor Cass Sunstein contends that "the very idea of a unitary unconstitutional conditions doctrine is a product of the view that the common law is the ordinary course and that government 'intervention' - the regulatory state - is exceptional."222 This view, I think, is profoundly mistaken. Under a minimalist state there is little need for an unconstitutional conditions doctrine. The function of an unconstitutional conditions doctrine is to preserve certain protected constitutional liberties in an environment of pervasive governmental activity. The unconstitutional conditions doctrine is not in opposition to the modern welfare-regulatory state; it is the constitutionalism of the welfare-regulatory state.

Professor Sunstein also claims that the question whether the denial of funds is a "penalty" or a "refusal to subsidize" "is almost impossible to sort out."223 Instead the question is "whether the governmental action at issue intrudes on the relevant right in a constitutionally troublesome way."224 This begs the question: what is a "constitutionally troublesome way"? To answer this question requires articulation of a theory. Nor is it sufficient simply to "ask $]$ whether . . . the government has constitutionally sufficient justifications for affecting constitutionally protected interests."225 How strong need the justifications be? How strict the scrutiny? When is it "sufficient" that the taxpayers, through their representatives, have determined that they prefer not to spend their money in that fashion, or that other public purposes have a higher priority? Without a general theory, these questions will be at the mercy of inconsistent and subjective judgments.

Professor Michael Seidman goes still further. He states that the selective funding problem, which he calls the "coercive offer problem," seems "difficult because it can be resolved only by reference to norms and conceptions that cannot be derived from the constitutional

222 Sunstein, supra note 21 , at 595 .

223 Sunstein, supra note 62 , at 343 .

224 Id.

225 Sunstein, supra note 21 , at 595 . 
text."226 He states that any solution to this problem "therefore brings into question the underlying legitimacy of prevailing textual theories of constitutional analysis"227 and suggests that judges and lawyers should engage in "perpetual context shifting"228 to "free themselves from the way things are and to imagine the different world that we [apparently meaning judges] might create."229 In his view, the selective funding problem becomes not merely difficult, but incoherent, a conclusion that leads to a call for abandonment of consistency.

I do not think a careful study of actual selective funding problems reveals such incoherence. In this Article, I have identified two "constitutionally troublesome ways" for the government to allocate its resources: to fund only one of two or more mutually exclusive, constitutionally protected choices, and to deny benefits to those who exercise a constitutional right beyond making them bear the direct cost of that exercise. I have, moreover, applied this analysis to two of the most seemingly intractable examples of selective funding, abortion and religious schooling. I believe that this general theory, coupled with the specifications of the nature of the constitutional rights involved, has yielded results that can be assessed objectively. If correct, this approach is superior to any conclusory or subjective approach. If incorrect, it should be replaced with a better theory, which would take the form of either alternative understandings of the rights or modifications in the general theory. To have no theory at all invites ad hoc decisionmaking and unfairness.

Resistance to a doctrine of unconstitutional conditions is found on both the left and the right of the jurisprudential spectrum. It comes both from those, like Professor Seidman, who profess to find constitutional law indeterminate and therefore open to social change through judicial creativity, and from those, like Chief Justice Rehnquist ${ }^{230}$ (and Justice Holmes in an earlier era ${ }^{231}$ ), who emphasize the democratic element in our constitutional system and who are reluctant to impose constitutional constraints on the allocative decisions of the representative branches. The common element of the left and the right is their tendency to undervalue the constitutional text, the former in favor of judicial, and the latter in favor of democratic, discretion. The doctrine of unconstitutional conditions, by contrast, belongs to

${ }^{226}$ Seidman, Reflections on Context and the Constitution, 73 MrNN. L. Rev. 73, 76 (1988).

227 Id.

228 Id. at 82 .

229 Id. at 84 .

230 See, e.g., South Dakota v. Dole, 483 U.S. 203 (1987) (Rehnquist, C.J.); Arnett v. Kennedy, 4 I6 U.S. 134 (1974) (plurality opinion) (Rehnquist, J.).

231 See, e.g., Frost \& Frost Trucking Co. v. Railroad Comm'n, 27I U.S. 583, 60I-02 (I926) (Holmes, J., dissenting); Western Union Tel. Co. v. Kansas, 216 U.S. I, 52-53 (1910) (Holmes, J., dissenting); Commonwealth v. Davis, I62 Mass. 5IO, 5 II, 39 N.E. II3, Ir3 (I895) (Holmes, J.), aff'd, I67 U.S. 43 (1897). 
an intermediate jurisprudential tradition of constitutionalism, in which the powers and discretion of both democratic and judicial decisionmakers are defined by the constitutional text, understood as a reasonably determinate and accessible set of principles.

The new critics of a doctrine of unconstitutional conditions do not seek a return to an ideology of judicial restraint and majoritarianism. They join in repudiating the old arguments - the right-privilege distinction, the greater-includes-the-lesser argument, and the exclusive focus on common law entitlements - that once were used to justify deference to selective funding schemes enacted by representative bodies. The new critics do not desire a restoration of the Holmes-Rehnquist position. Instead they claim that the doctrine is incoherent, an anachronism that cannot provide answers to today's constitutional questions. The difficulty with their position is that it calls on us to replace the older tradition of judicial restraint with little more than intuitions tailored to each individual constitutional right, without regard to consistency of methodology.

The difficulty with the conservative-democratic position (which in an earlier era was the progressive-democratic position) is that it sweeps too broadly, impeding not only usurpations of legislative power by the judiciary but also legitimate invocations of constitutional rights. Restraint is an admirable attribute in a judge, but deference to the legislature does a disservice to the Constitution when the Constitution is intended to limit legislative power. In the modern welfare-regulatory state, much of the power of government lies in its ability to allocate burdens and benefits, short of criminal sanction or invasion of common law rights. If the allocation of burdens and benefits were free from constitutional scrutiny, much of the constitutional structure of individual rights and limited government would become irrelevant. Today, a doctrine of unconstitutional conditions is an indispensable part of constitutionalism.

The questions of abortion funding and religious school funding illustrate not just the utility of, but also the need for, a consistent theory of selective funding. Given the intense ideological passions generated by these questions, who can trust the mere mortals sitting as article III judges to decide these questions dispassionately, if they are free to address them on an ad hoc basis? It would be naive to believe that complex constitutional theory is a perfect constraint on politicized judging, but I am confident that a judge forced to develop doctrine that would govern both abortion and religious education will be more constrained, dispassionate, and fair-minded than one who decides what seems fair in each case as it comes. 